\title{
A 19 Year Analysis of Small Mammals Associated with Human Hantavirus Cases in Chile
}

\author{
Fernando Torres-Pérez ${ }^{1, *,+}{ }^{*}$, R. Eduardo Palma ${ }^{2,+}$, Dusan Boric-Bargetto ${ }^{1}$, Cecilia Vial ${ }^{3}$ (D), \\ Marcela Ferrés ${ }^{4}$, Pablo A. Vial ${ }^{5}$, Constanza Martínez-Valdebenito ${ }^{4}$, Carlos Pavletic ${ }^{6, \ddagger}$, \\ Alonso Parra ${ }^{6}$, Pablo A. Marquet ${ }^{7}(1)$ and Gregory J. Mertz ${ }^{8}$ \\ 1 Instituto de Biología, Pontificia Universidad Católica de Valparaíso, Valparaíso 2373223, Chile; \\ dboricbargetto@gmail.com \\ 2 Laboratorio de Biología Evolutiva, Departamento de Ecología, Pontificia Universidad Católica de Chile; \\ Santiago 8331150, Chile; epalma@bio.puc.cl \\ 3 Programa Hantavirus, Instituto de Ciencias e Innovación en Medicina, Facultad de Medicina, Clínica \\ Alemana, Universidad del Desarrollo, Santiago 7610658, Chile; mcvial@udd.cl \\ 4 Laboratorio de Infectología y Virología Molecular, Red Salud UC-Christus, Departamento de Enfermedades \\ Infecciosas e Inmunología Pediátricas, Pontificia Universidad Católica de Chile, Santiago 8330024, Chile; \\ marceferres@gmail.com (M.F.); constanza.martinez.v@gmail.com (C.M.-V.) \\ 5 Instituto de Ciencias e Innovación en Medicina, Facultad de Medicina, Clínica Alemana, Universidad del \\ Desarrollo, Santiago 7610658, Chile; pvial@udd.cl \\ 6 Oficina de Zoonosis y Control de Vectores, División de Políticas Publicas Saludables y Promoción, \\ Subsecretaría de Salud Pública, Ministerio de Salud, Santiago 8320064, Chile; alonsoparra@minsal.cl \\ 7 Departamento de Ecología, Pontificia Universidad Católica de Chile, Santiago 8331150, Chile; \\ pmarquet@bio.puc.cl \\ 8 Division of Infectious Diseases, Department of Internal Medicine, University of New Mexico, \\ Albuquerque 87131, New Mexico; gmertz@salud.unm.edu \\ * Correspondence: fernando.torres@pucv.cl; Tel.: +56-32-227-4849 \\ + These authors contributed equally to this work. \\ $\ddagger$ Deceased.
}

Received: 26 July 2019; Accepted: 9 September 2019; Published: 12 September 2019

\begin{abstract}
Small mammals present in areas where hantavirus cardiopulmonary syndrome (HCPS) cases had occurred in central and southern Chile were captured and analyzed to evaluate the abundance of rodents and seroprevalence rates of antibodies to Andes orthohantavirus (ANDV). Sampling areas ranged from the Coquimbo to Aysén regions (30-45 S approx.) regions. Ninety-two sites in peridomestic and countryside areas were evaluated in 19 years of sampling. An antibody against ANDV was detected by strip immunoassay in 58 of 1847 specimens captured using Sherman traps. Of the eleven species of rodents sampled, Abrothrix olivacea, Oligoryzomys longicaudatus and Abrothrix hirta were the most frequently trapped. O. longicaudatus had the highest seropositivity rate, and by logistic regression analysis, O. longicaudatus of at least $60 \mathrm{~g}$ had $80 \%$ or higher probability to be seropositive. Sex, age and wounds were significantly related to seropositivity only for O. longicaudatus. Across administrative regions, the highest seropositivity was found in the El Maule region (34.8-36.2 $\left.{ }^{\circ} \mathrm{S}\right)$, and the highest number of HCPS cases was registered in the Aysén region. Our results highlight the importance of long term and geographically extended studies, particularly for highly fluctuating pathogens and their reservoirs, to understand the implications of the dynamics and transmission of zoonotic diseases in human populations.
\end{abstract}

Keywords: Andes orthohantavirus; Chile; hantavirus cardiopulmonary syndrome; hantavirus spatial distribution; Oligoryzomys longicaudatus; peridomestic; rodent reservoir; seroprevalence 


\section{Introduction}

Emerging zoonotic diseases are a major concern for public health systems, producing new or previously unrecognized diseases, or rapidly increasing incidence of infection in the human population. Ecological, environmental changes or changes in human demographics and behavior, which increase chances of contact with reservoirs, are the main factors responsible for these emergences [1]. RNA viruses represent an important group of emerging human pathogens, including several harbored by animal reservoirs [2]. Recent examples are the outbreak of pandemic influenza A subtype H1N1, human immunodeficiency virus, Ebola virus, hepatitis $C$ virus, West Nile virus, rabies virus and severe adult respiratory distress (SARS), which have challenged control and prevention measures of health systems.

Orthohantaviruses are segmented negative-strand RNA viruses of the family Hantaviridae, which contain large (L), medium (M) and small (S) segments encoding RNA-dependent RNA polymerase, glycoproteins $\mathrm{Gn}$ and $\mathrm{Gc}$ and nucleocapsid (N) protein, respectively [3]. Several orthohantavirus strains are recognized as human pathogens [4-6]. Orthohantavirus infections became a concern in the Americas in 1993 after detecting an outbreak of a previously unrecognized syndrome [7]. The disease (hantavirus cardiopulmonary syndrome, HCPS), was produced by infection with the newly-discovered Sin Nombre virus (SNV), with Peromyscus maniculatus (deer mouse) identified as the reservoir [8]. Since then, more than forty-three genotypes have been reported in the Americas alone [5], with nearly half of those associated with clinical cases of HCPS. Pathogenic hantaviruses are carried by rodents of the families Muridae and Cricetidae, while hantaviruses of unknown pathogenicity have also been discovered in shrews, moles and bats [9-13]. Hantavirus infection is transmitted to humans via inhalation of contaminated rodent excreta and secretions or less commonly through rodent bites [5]; the case fatality rate in the Americas is around 36\% [6,14-16], although it may reach up to 56\% [17].

In southern South America, Andes orthohantavirus (ANDV) is a major etiologic agent of HCPS, and the sigmodontine rodent Oligoryzomys longicaudatus (the pigmy rice rat) is the reservoir [18,19]. O. longicaudatus is distributed in Chile and Argentina, with higher abundances in mesic areas in the temperate forests and Patagonia [20]. Spillover has been reported to other sympatric rodent species, although with no apparent epidemiological importance [21]. Strikingly, person-to-person transmission of hantavirus infection has only been demonstrated for ANDV [16,22-25].

In Chile, 1157 cases have been confirmed between 1995 and December 2018 in 11 administrative regions from the Coquimbo region in the north to the Aysén region in the south (30-45 $\mathrm{S}$ approx.; epi.minsal.cl). Although human infections have been reported in a variety of environments, higher numbers of HCPS cases tend to be associated with people living, working or visiting rural areas where the reservoir occurs $[20,26]$. The settlement of human populations in areas near habitats where wild infected rodents occur increases the likelihood of contact and the probability of contracting the infection. Although the relation between the number of infected hosts and human incidence depends on complex ecological processes [27], there is evidence suggesting that higher seroprevalence in the hantavirus reservoir may lead to more human infections [28]. To understand eco-epidemiological processes that might be responsible for human hantavirus infections, we undertook an analysis of the abundance and seroprevalence of small mammals in Chile in peridomestic and countryside locations where cases of HCPS had occurred. To date, O. longicaudatus is the sole recognized reservoir for ANDV in Chile, and only a few studies have explored the participation of other small mammal species in the transmission of the disease $[19,29]$. Our study highlights the value of combining information from reservoir ecology, epidemiology and geography to gain insights into the persistence and transmission of zoonotic diseases. 


\section{Materials and Methods}

\subsection{Ethical Statement}

Permission to trap small mammals was obtained from the Servicio Agrícola y Ganadero (SAG, Chile; permits 4560/2018, 5346/2016, 3432/2013, 7445/2013, 1607-2012, 6134-2011, 1158/2011, 17/2000, 7325/2005, 1056/1999), and Corporación Nacional Forestal (CONAF, Chile; permits 10-02/2002, 13-03/2003, 14-99/2004, 24/2004, 07-06/2006). All the National Institute of Health studies were approved by the Institutional Animal Care and Use Committee (IACUC) of the University of New Mexico Health Sciences Center under protocol number 14-101118-Field-HSC, and the Department of Health and Human Services of the National Institute of Health, Animal Welfare Assurance A5848-01. Small mammals trapping protocols and biosafety procedures for CONICYT-FONDECYT and CONICYTY-PIA Anillo studies (Chile), were reviewed and approved by institutional ethics and biosafety review boards at the Pontificia Universidad Católica de Valparaíso (certifications CBPUCV 22.04.2011, CBPUCV 11.2015, CBPUCV 06.2017), and the Pontificia Universidad Católica de Chile (CBB 7/8/2005; CBB 181/2010; CBB-143/2011).

\subsection{Sampling}

Sampling was conducted in those areas where human cases of HCPS were confirmed through the Chilean Ministry of Health (see below). When more than one case was reported simultaneously, we chose that site that was not sampled previously and/or involved more people that contracted the disease. Sampling was performed within eight weeks after the onset of symptoms in the index case. We also chose sampling sites according to the following characteristics: Availability of sampling execution, sites where vegetation characteristics would be part of the habitat of the primary reservoir rodent O. longicaudatus, and sites where the local population reported seeing rodents or rodent droppings. The study covered rural, urban and periurban areas [20] ranging from Chiñigue, Coquimbo region

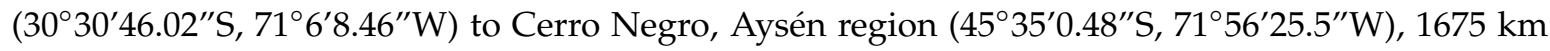
north to south. To capture small mammals, standard live Sherman traps $(8 \mathrm{~cm} \times 9 \mathrm{~cm} \times 23 \mathrm{~cm})$ were used. Traps were located in forests, meadows, plantations and along fences and roads [20,30]. Traps were installed for three consecutive nights varying between 120-771 traps/night. For the capture and manipulation of small mammals, the processing and handling standards were followed according to the protocols of the Center for Infectious Diseases and Prevention of Atlanta [30,31] and the American Society of Mammalogists [32]. Species identification followed specialized literature. We also followed the recent description of $A$. hirta $\left(35^{\circ} \mathrm{S}\right.$ to north of Tierra del Fuego) as sister species of $A$. longipilis (distributed between $30^{\circ} \mathrm{S}$ to $35^{\circ} \mathrm{S}$ approx.) [33,34].

\subsection{Relative Abundance}

Relative abundance was determined for all captured species (O. longicaudatus, A. olivacea, A. longipilis, A. hirta, A. sanborni, A. manni, L. micropus, P. darwini, M. musculus, $R$. norvegicus and $R$. rattus) between years 2000 and 2018. Each sampling site was categorized by locality (including county), administrative region (from the Coquimbo to Aysén), sampling year and coordinates. The relative abundance for each species and sampling site was measured by the number of individuals captured per species/total number of traps) $\times 100[20,30]$.

\subsection{Relative Seropositivity}

Small mammals captured were anesthetized and a blood sample was taken from the retro-orbital sinus by means of a heparinized capillary, or by cardiac puncture. Blood samples were placed in cryovials and preserved in liquid nitrogen and brought to the laboratory for analysis. In addition, for each specimen the heart, kidney, spleen, liver and lung were extracted, and stored in liquid nitrogen. Voucher specimens were preserved in 96\% ethanol, and deposited in the Colección de Flora y Fauna, Pontificia Universidad Católica de Valparaíso (Valparaíso, Chile), Colección de Flora y Fauna, Professor 
Patricio Sánchez Reyes, Pontificia Universidad Católica de Chile (Santiago, Chile) and in the Division of Mammals of the Museum of Southwestern Biology, University of New Mexico (Albuquerque, NM). For the determination of antibodies against ANDV, the SIA (strip immunoassay vacuum-blot test) technique was used following the method described previously (2004) [20,35].

To determine the relative intraspecific seropositivity for hantavirus by locality, the presence of antibodies to the virus was standardized using the ratio between the number of seropositive at each sampled locality and the trapping success (number of captures by number of total traps-nights). All values were determined for O. longicaudatus, A. hirta and A. olivacea that resulted positive for antibodies against the ANDV [36]. In addition, the total relative seropositivity by sampling site (total seropositives of the locality/trapping effort) and by region (total seropositives of the region/trapping effort) was estimated.

\subsection{Confirmed Human Cases of Hantavirus}

The confirmed human cases of hantavirus between 2000 and 2018 were obtained using two sources of information: (i) Through a national research network established by the Hantavirus Program in which HCPS cases were enrolled in clinical research studies shortly after hospital admission, and (ii) through the National Notification report of the Ministry of Health. HCPS is a disease that must be reported as soon as the diagnosis is suspected. Human cases were classified by locality and the administrative region.

\subsection{Ecological Features of the Reservoirs}

To determine the relationship between seropositives and age, small mammals were sexed and classified by age into juveniles or adults according to their body mass and reproductive status (i.e., males with scrotal or abdominal testes and females with or without perforated vagina, pregnant and/or lactogenic) $[37,38]$. We also registered presence or absence of wounds or scars, such as bites on the ears or tail, to determine the relationship between seropositives and wounds.

\subsection{Data Analysis and Statistics}

The $\chi 2$ test and Fisher's exact test were used to compare the following categorical variables between groups using $2 \times 2$ tables: Serostatus (seropositive or seronegative) according to sex (male or female), age (adult or juvenile) and wounds (injured or not injured). The significance criterion was set at $p<0.05$. Calculations were performed using the VassarStats website for statistical computation (http://www.vassarstats.net). The effect of the weight (independent variable) on the serostatus (response variable) was analyzed by using a logistic regression performed within the free data analysis environment $R$ [39].

\subsection{Serology and Human Hantavirus Cases}

We determined the rodents' relative seropositivity in sites associated with human hantavirus cases, and human hantavirus cases across the 11 sampled administrative regions in Chile. The numbers of human hantavirus cases were standardized to cases per 1000 rural inhabitants (information extracted from the National Institute of Statistic of Chile, www.ine.cl).

\section{Results}

\subsection{Rodents Relative Abundance}

During nineteen years of sampling (2000-2018), ninety-two sites associated with human hantavirus cases between Coquimbo and Aysén (30-45 S approx.) regions in Chile were studied for the presence of rodents (Figure 1). We trapped a total of 1847 specimens of eleven species of rodents. The sigmodontine species captured were Oligoryzomys longicaudatus $(N=631)$, Abrothrix olivacea $(N=636)$, Abrothrix longipilis $(N=43)$, Abrothrix hirta $(N=234)$, Abrothrix sanborni $(N=9)$, Abrothrix manni $(N=8)$, 
Loxodontomys micropus $(N=18)$ and Phyllotis darwini $(N=18)$. Murine rodents captured were Mus musculus $(N=52)$, Rattus norvegicus $(N=95)$ and Rattus rattus $(N=103)$. Overall, rodents were captured in all sampling sites, and seropositive specimens were found in 30 of the 92 sites (see below).

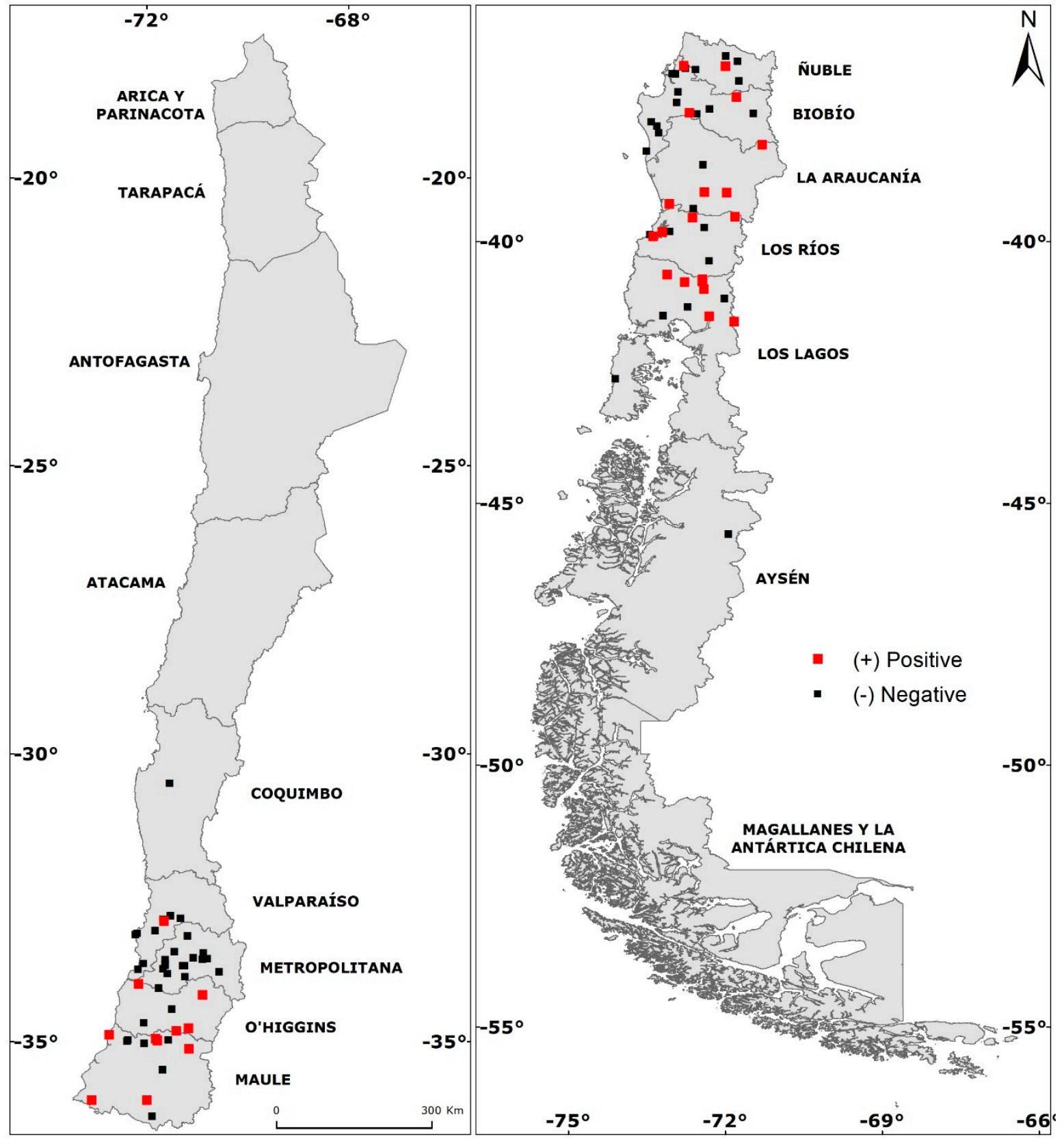

Figure 1. Small mammal trapping sites associated with human hantavirus cases sampled in the nineteen-year study across administrative regions in Chile. Sites with small mammals seropositive for anti-Andes orthohantavirus (ANDV) antibodies are shown in red. Sites without seropositive rodents are shown in black. 
Relative abundance (Table 1, Appendix A) of rodents ranged between 17.5 (O. longicaudatus, Nancul, Panguipulli, Los Ríos region) to 0.13 (A. hirta, L. micropus and R. rattus; Las Quemas, Puerto Montt, Los Lagos region). The highest relative abundance for O. longicaudatus was found in Nancul, Panguipulli, Los Ríos region (17.5), and the lowest was found in Las Peñas 2002, San Fernando, O'Higgins region (0.28). For A. olivacea, the highest relative abundance was found in Alto Las Viñas, Los Ángeles, Biobío region (8.67), and the lowest value was 0.15 in Tres Esquinas, Coihueco (Ñuble region). Relative abundance for A. longipilis ranged from 4.0 in Fundo La Ventolera, Santo Domingo (Valparaíso region) to 0.33 in Quilamuta-Las Cabras ( $\mathrm{O}^{\prime}$ Higgins region). For $A$. hirta, the highest value of relative abundance was in Vilumanque, Concepción (Biobío region; 8.72), and the lowest relative abundance was in Las Quemas, Puerto Montt (Los Lagos region; 0.13). For A. sanborni the highest value of relative abundance was in Chiloé National Park (Los Lagos region; 1.04), and the lowest relative abundance was in Fundo Futangue, Lago Ranco (Los Ríos region; 0.73). Relative abundance for L. micropus ranged from 1.67 in Llanquén, Lonquimay (Araucanía region) to 0.13 in Las Quemas, Puerto Montt (Los Lagos region). For P. darwini, values ranged from 1.38 in Coya, Machalí (O'Higgins region) to 0.33 in Las Peñas 2018 (O'Higgins region). Among murine rodents, values ranged between 2.53 (Llaillay, Valparaíso region) to 0.15 (Los Maitenes, Lolol, O'Higgins region) in Mus musculus. Similar values of relative seropositivity were found for both Rattus species: For R. norvegicus values ranged from 3.45 in Coya (O'Higgins region) to 0.15 in Chiloé National Park (Los Lagos region), and for $R$. rattus values ranged from 3.55 in Boroa Norte, Toltén (Araucanía region) to 0.13 in Las Quemas, Puerto Montt (Los Lagos region).

\subsection{Total Seropositivity}

Globally, of the 1847 small mammals analyzed for antibodies against the ANDV, 58 were seropositive; thus the total seroprevalence of hantavirus antibodies in small mammals was $3.14 \%$. The seroprevalence for O. longicaudatus was $2.22 \%, 0.65 \%$ for A. hirta and $0.27 \%$ for A. olivacea. The distribution of seropositives is shown in Figure 2. The total relative seropositivity (including all seropositives and all captured species per locality) was higher in Los Queñes, Romeral (1.64) and lower in Paso El León (Cochamó, Los Lagos region) and Colico (Cunco, Araucanía region; 0.06). By administrative region, relative seropositivities were 0.11 (Nuble region), 0.25 (Valparaíso region), 1.4 (O’Higgins region), 1.28 (Biobío region), 1.42 (Los Lagos region), 1.46 (Araucanía region), 1.39 (Los Ríos region) and 3.03 (El Maule region). Despite HCPS cases reported in Coquimbo and Aysén regions, no seropositive rodents were detected (Table 1). No seropositive rodents were also found in the Metropolitan region despite sampling in 14 localities (Table 1) and registering 54 HCPS cases. 
Table 1. Relative abundance and relative seropositivity to ANDV by locality and species.

\begin{tabular}{|c|c|c|c|c|c|c|c|c|c|c|c|c|c|c|c|c|}
\hline \multirow[b]{2}{*}{ Locality, County } & \multirow[b]{2}{*}{$\begin{array}{l}\text { Administrative } \\
\text { Region }\end{array}$} & \multicolumn{11}{|c|}{ Relative Abundance } & \multicolumn{4}{|c|}{ Relative Seropositivity } \\
\hline & & Al & Ah & Ao & As & Am & Lm & Ol & $\mathbf{P d}$ & $\mathrm{Mm}$ & $\mathbf{R n}$ & $\mathbf{R r}$ & $\mathrm{Ol}$ & Ah & Ao & Total \\
\hline Chiñigue, Ovalle & Coquimbo & 1.00 & 0.00 & 2.33 & 0.00 & 0.00 & 0.00 & 0.00 & 0.00 & 0.67 & 0.67 & 0.33 & 0.00 & 0.00 & 0.00 & 0.00 \\
\hline Fundo Chuico Blanco, Hijuelas & Valparaíso & 0.00 & 0.00 & 0.00 & 0.00 & 0.00 & 0.00 & 0.37 & 0.00 & 0.00 & 1.11 & 0.00 & 0.00 & 0.00 & 0.00 & 0.00 \\
\hline Llaillay, Llaillay & Valparaíso & 0.00 & 0.00 & 0.42 & 0.00 & 0.00 & 0.00 & 0.00 & 0.00 & 2.53 & 0.42 & 0.00 & 0.00 & 0.00 & 0.00 & 0.00 \\
\hline Lo Mardones, Quillota & Valparaíso & 0.00 & 0.00 & 2.06 & 0.00 & 0.00 & 0.00 & 0.48 & 0.00 & 0.63 & 0.95 & 0.00 & 0.00 & 0.00 & 0.00 & 0.00 \\
\hline La Palma, Quillota & Valparaíso & 0.00 & 0.00 & 0.33 & 0.00 & 0.00 & 0.00 & 0.33 & 0.00 & 0.00 & 0.83 & 0.17 & 3.00 & 0.00 & 0.00 & 0.60 \\
\hline Población Prat, Villa Alemana & Valparaíso & 0.00 & 0.00 & 4.67 & 0.00 & 0.00 & 0.00 & 0.00 & 0.00 & 1.00 & 0.00 & 0.33 & 0.00 & 0.00 & 0.00 & 0.00 \\
\hline Laguna Verde, Valparaíso & Valparaíso & 0.83 & 0.00 & 0.56 & 0.00 & 0.00 & 0.00 & 0.00 & 0.00 & 0.00 & 0.56 & 0.00 & 0.00 & 0.00 & 0.00 & 0.00 \\
\hline Las Docas, Valparaíso & Valparaíso & 3.23 & 0.00 & 0.40 & 0.00 & 0.00 & 0.00 & 1.41 & 1.01 & 0.00 & 0.00 & 0.00 & 0.00 & 0.00 & 0.00 & 0.00 \\
\hline Alto el Manzano, TilTil & Metropolitan & 0.00 & 0.00 & 0.00 & 0.00 & 0.00 & 0.00 & 0.00 & 0.00 & 2.33 & 0.00 & 0.00 & 0.00 & 0.00 & 0.00 & 0.00 \\
\hline San Antonio de Naltahua, Isla de Maipo & Metropolitan & 0.00 & 0.00 & 0.67 & 0.00 & 0.00 & 0.00 & 0.00 & 0.00 & 0.00 & 0.00 & 0.67 & 0.00 & 0.00 & 0.00 & 0.00 \\
\hline La Reina, La Reina & Metropolitan & 0.00 & 0.00 & 0.67 & 0.00 & 0.00 & 0.00 & 0.00 & 0.00 & 0.00 & 0.00 & 2.00 & 0.00 & 0.00 & 0.00 & 0.00 \\
\hline Lo Espejo, Lo Espejo & Metropolitan & 0.00 & 0.00 & 0.50 & 0.00 & 0.00 & 0.00 & 0.00 & 0.00 & 0.33 & 0.17 & 0.00 & 0.00 & 0.00 & 0.00 & 0.00 \\
\hline El Canelo, San José de Maipo & Metropolitan & 0.00 & 0.00 & 0.00 & 0.00 & 0.00 & 0.00 & 0.39 & 0.39 & 0.00 & 0.39 & 0.78 & 0.00 & 0.00 & 0.00 & 0.00 \\
\hline La Florida Alto, La Florida & Metropolitan & 0.37 & 0.00 & 3.33 & 0.00 & 0.00 & 0.00 & 0.00 & 0.00 & 0.00 & 0.00 & 0.00 & 0.00 & 0.00 & 0.00 & 0.00 \\
\hline Mallarauco, Melipilla & Metropolitan & 0.00 & 0.00 & 1.67 & 0.00 & 0.00 & 0.00 & 0.33 & 0.00 & 2.00 & 0.00 & 0.00 & 0.00 & 0.00 & 0.00 & 0.00 \\
\hline San Antonio, San Antonio & Valparaíso & 0.00 & 0.00 & 0.00 & 0.00 & 0.00 & 0.00 & 0.44 & 0.00 & 1.33 & 0.00 & 0.89 & 0.00 & 0.00 & 0.00 & 0.00 \\
\hline Pomaire, Melipilla & Metropolitan & 0.00 & 0.00 & 0.89 & 0.00 & 0.00 & 0.00 & 0.00 & 0.00 & 0.00 & 0.22 & 0.22 & 0.00 & 0.00 & 0.00 & 0.00 \\
\hline Constructora Inca, Melipilla & Metropolitan & 0.00 & 0.00 & 2.56 & 0.00 & 0.00 & 0.00 & 0.00 & 0.00 & 0.32 & 0.00 & 0.00 & 0.00 & 0.00 & 0.00 & 0.00 \\
\hline Condominio Puerta del Sol, Talagante & Metropolitan & 0.00 & 0.00 & 1.33 & 0.00 & 0.00 & 0.00 & 0.33 & 0.00 & 0.00 & 0.00 & 0.00 & 0.00 & 0.00 & 0.00 & 0.00 \\
\hline Talagante, Talagante & Metropolitan & 0.00 & 0.00 & 6.67 & 0.00 & 0.00 & 0.00 & 0.00 & 0.00 & 0.42 & 2.08 & 0.00 & 0.00 & 0.00 & 0.00 & 0.00 \\
\hline Chocalán, Melipilla & Metropolitan & 0.00 & 0.00 & 3.67 & 0.00 & 0.00 & 0.00 & 0.33 & 0.00 & 0.00 & 0.67 & 0.00 & 0.00 & 0.00 & 0.00 & 0.00 \\
\hline Fundo La Ventolera, Santo Domingo & Valparaíso & 4.00 & 0.00 & 6.67 & 0.00 & 0.00 & 0.00 & 0.00 & 0.00 & 0.00 & 0.67 & 0.00 & 0.00 & 0.00 & 0.00 & 0.00 \\
\hline El Ingenio, San José de Maipo & Metropolitan & 0.00 & 0.00 & 0.33 & 0.00 & 0.00 & 0.00 & 0.00 & 0.00 & 0.00 & 0.33 & 0.00 & 0.00 & 0.00 & 0.00 & 0.00 \\
\hline Hijuelas, Hijuelas & Valparaíso & 0.00 & 0.00 & 0.95 & 0.00 & 0.00 & 0.00 & 0.00 & 0.00 & 0.95 & 0.48 & 0.00 & 0.00 & 0.00 & 0.00 & 0.00 \\
\hline Abrantes, Paine & Metropolitan & 0.00 & 0.00 & 1.00 & 0.00 & 0.00 & 0.00 & 0.00 & 0.00 & 0.33 & 0.33 & 1.00 & 0.00 & 0.00 & 0.00 & 0.00 \\
\hline Ucúquer, Litueche & O'Higgins & 0.00 & 0.00 & 3.11 & 0.00 & 0.00 & 0.00 & 1.33 & 1.33 & 0.00 & 0.00 & 1.11 & 0.00 & 0.00 & 0.32 & 0.15 \\
\hline Quilamuta-Las Cabras, Las Cabras & O'Higgins & 0.33 & 0.00 & 1.00 & 0.00 & 0.00 & 0.00 & 2.67 & 0.00 & 0.00 & 0.67 & 0.00 & 0.00 & 0.00 & 0.00 & 0.00 \\
\hline Coya, Machalí & O'Higgins & 0.00 & 0.00 & 0.69 & 0.00 & 0.00 & 0.00 & 0.69 & 1.38 & 0.00 & 3.45 & 0.00 & 1.45 & 0.00 & 0.00 & 0.16 \\
\hline $\begin{array}{c}\text { Sn Vicente de Tagua Tagua, Sn Vicente de } \\
\text { Tagua Tagua }\end{array}$ & O’Higgins & 0.00 & 0.00 & 0.28 & 0.00 & 0.00 & 0.00 & 0.00 & 0.00 & 0.42 & 0.00 & 0.14 & 0.00 & 0.00 & 0.00 & 0.00 \\
\hline Los Maitenes, Lolol & O'Higgins & 0.00 & 0.00 & 0.46 & 0.00 & 0.00 & 0.00 & 0.31 & 0.00 & 0.15 & 0.31 & 0.00 & 0.00 & 0.00 & 0.00 & 0.00 \\
\hline Las Peñas, San Fernando 2002 & O'Higgins & 0.00 & 0.00 & 0.56 & 0.00 & 0.00 & 0.00 & 0.28 & 0.00 & 0.00 & 0.00 & 0.00 & 3.60 & 0.00 & 0.00 & 1.20 \\
\hline Las Peñas, San Fernando 2018 & O'Higgins & 0.00 & 0.00 & 1.33 & 0.00 & 0.00 & 0.00 & 0.00 & 0.33 & 0.00 & 0.50 & 1.00 & 0.00 & 0.00 & 0.00 & 0.00 \\
\hline El Sauce, Chimbarongo & O'Higgins & 0.00 & 0.00 & 2.31 & 0.00 & 0.00 & 0.00 & 0.77 & 0.00 & 0.00 & 0.00 & 0.26 & 1.30 & 0.00 & 0.00 & 0.30 \\
\hline Lipimávida, Vichuquén & Maule & 0.44 & 0.00 & 0.22 & 0.00 & 0.00 & 0.00 & 1.78 & 0.00 & 0.00 & 0.00 & 0.00 & 0.00 & 0.00 & 0.00 & 0.00 \\
\hline Duao, Licantén & Maule & 1.00 & 0.00 & 8.00 & 0.00 & 0.00 & 0.00 & 12.33 & 0.00 & 0.00 & 0.67 & 0.00 & 0.32 & 0.00 & 0.00 & 0.18 \\
\hline Escuela Quilpoco, Rauco & Maule & 0.00 & 0.00 & 0.00 & 0.00 & 0.00 & 0.00 & 0.37 & 0.00 & 0.37 & 1.11 & 0.00 & 2.70 & 0.00 & 0.00 & 0.54 \\
\hline
\end{tabular}


Table 1. Cont.

\begin{tabular}{|c|c|c|c|c|c|c|c|c|c|c|c|c|c|c|c|c|}
\hline \multirow[b]{2}{*}{ Locality, County } & \multirow[b]{2}{*}{$\begin{array}{l}\text { Administrative } \\
\text { Region }\end{array}$} & \multicolumn{11}{|c|}{ Relative Abundance } & \multicolumn{4}{|c|}{ Relative Seropositivity } \\
\hline & & Al & Ah & Ao & As & Am & Lm & Ol & Pd & Mm & Rn & $\mathbf{R r}$ & $\mathrm{Ol}$ & Ah & Ao & Total \\
\hline El Pumaitén, Romeral & Maule & 0.67 & 0.00 & 3.00 & 0.00 & 0.00 & 0.00 & 0.33 & 0.00 & 0.00 & 0.00 & 0.67 & 0.00 & 0.00 & 0.00 & 0.00 \\
\hline Hualañé, Hualañé 2010 & Maule & 0.00 & 0.00 & 0.22 & 0.00 & 0.00 & 0.00 & 1.33 & 0.00 & 0.00 & 0.00 & 0.00 & 0.00 & 0.00 & 0.00 & 0.00 \\
\hline El Trapiche, Curicó & Maule & 0.00 & 0.00 & 3.00 & 0.00 & 0.00 & 0.00 & 1.00 & 0.00 & 0.33 & 0.17 & 0.50 & 1.00 & 0.00 & 0.00 & 0.20 \\
\hline Hualañé, Hualañé 2012 & Maule & 0.00 & 0.00 & 3.06 & 0.00 & 0.00 & 0.00 & 0.56 & 0.00 & 0.00 & 0.00 & 0.00 & 0.00 & 0.00 & 0.00 & 0.00 \\
\hline Palquibudi, Rauco & Maule & 0.00 & 0.00 & 0.74 & 0.00 & 0.00 & 0.00 & 0.37 & 0.00 & 0.00 & 0.37 & 0.00 & 0.00 & 0.00 & 0.00 & 0.00 \\
\hline Los Queñes, Romeral & Maule & 0.00 & 0.00 & 0.28 & 0.00 & 0.00 & 0.00 & 1.11 & 0.00 & 0.00 & 0.28 & 1.39 & 3.60 & 0.00 & 3.60 & 1.64 \\
\hline Las Lomas, San Clemente & Maule & 0.00 & 0.00 & 0.67 & 0.00 & 0.00 & 0.00 & 0.00 & 0.00 & 0.00 & 0.00 & 0.67 & 0.00 & 0.00 & 0.00 & 0.00 \\
\hline Canal Melado, Longaví & Maule & 0.00 & 0.27 & 1.87 & 0.00 & 0.00 & 0.00 & 0.80 & 0.00 & 0.00 & 0.00 & 0.00 & 1.25 & 0.00 & 0.00 & 0.34 \\
\hline Retupel, Cauquenes & Maule & 0.00 & 0.00 & 2.33 & 0.00 & 0.00 & 0.00 & 1.67 & 0.00 & 0.00 & 0.00 & 0.00 & 0.60 & 0.00 & 0.00 & 0.25 \\
\hline Bullileo, Parral & Maule & 0.00 & 0.42 & 0.00 & 0.00 & 0.00 & 0.00 & 1.25 & 0.00 & 0.00 & 0.42 & 1.25 & 0.00 & 0.00 & 0.00 & 0.00 \\
\hline San Miguel de Ablemo, San Carlos & Ñuble & 0.00 & 0.00 & 7.10 & 0.00 & 0.00 & 0.00 & 3.09 & 0.00 & 0.00 & 0.93 & 1.54 & 0.00 & 0.00 & 0.00 & 0.00 \\
\hline Tres Esquinas, Coihueco & Biobío & 0.00 & 0.00 & 0.15 & 0.00 & 0.00 & 0.00 & 0.00 & 0.00 & 0.00 & 0.00 & 0.00 & 0.00 & 0.00 & 0.00 & 0.00 \\
\hline Agua Tendida, Tomé & Biobío & 0.00 & 3.67 & 5.67 & 0.00 & 0.00 & 0.00 & 3.33 & 0.67 & 0.00 & 0.33 & 0.33 & 0.60 & 0.27 & 0.00 & 0.21 \\
\hline Chillán-Pinto, Chillán & Ñuble & 0.00 & 1.33 & 7.67 & 0.00 & 0.00 & 0.00 & 3.00 & 0.00 & 0.33 & 0.33 & 0.67 & 0.33 & 0.00 & 0.00 & 0.08 \\
\hline Lloicura, Tomé & Biobío & 0.00 & 1.63 & 0.00 & 0.00 & 0.00 & 0.00 & 0.00 & 0.00 & 0.00 & 0.00 & 0.33 & 0.00 & 0.00 & 0.00 & 0.00 \\
\hline Peñablanca, Quillón & Ñuble & 0.00 & 0.35 & 1.39 & 0.00 & 0.00 & 0.00 & 2.08 & 0.00 & 0.00 & 1.04 & 0.69 & 0.00 & 0.00 & 0.00 & 0.00 \\
\hline Vilumanque, Concepción & Biobío & 0.00 & 8.72 & 8.26 & 0.00 & 0.00 & 0.00 & 11.93 & 0.00 & 0.00 & 0.00 & 0.46 & 0.00 & 0.00 & 0.00 & 0.00 \\
\hline Chaimávida, Concepción & Biobío & 0.00 & 0.44 & 1.11 & 0.00 & 0.00 & 0.00 & 2.89 & 0.00 & 0.00 & 0.00 & 0.00 & 0.00 & 0.00 & 0.00 & 0.00 \\
\hline Forestal Millalemu, El Carmen & Ñuble & 0.00 & 0.67 & 0.89 & 0.00 & 0.00 & 0.00 & 4.22 & 0.00 & 0.00 & 0.00 & 0.22 & 0.00 & 0.00 & 0.00 & 0.00 \\
\hline Talcamávida, Hualqui & Biobío & 0.00 & 1.56 & 0.67 & 0.00 & 0.00 & 0.00 & 1.56 & 0.00 & 0.44 & 0.00 & 0.22 & 0.00 & 0.00 & 0.00 & 0.00 \\
\hline Forestal Millalemu, Tucapel & Biobío & 0.00 & 1.33 & 7.00 & 0.00 & 0.00 & 0.00 & 3.00 & 0.00 & 0.00 & 0.00 & 0.33 & 0.67 & 0.00 & 0.00 & 0.17 \\
\hline Santa Juana, Santa Juana & Biobío & 0.00 & 0.67 & 0.00 & 0.00 & 0.00 & 0.00 & 2.22 & 0.00 & 0.00 & 0.44 & 0.00 & 0.00 & 0.00 & 0.00 & 0.00 \\
\hline Los Ángeles, Los Ángeles & Biobío & 0.00 & 0.00 & 1.28 & 0.00 & 0.00 & 0.00 & 0.00 & 0.00 & 0.00 & 0.64 & 0.00 & 0.00 & 0.00 & 0.00 & 0.00 \\
\hline Cañicura, Quilleco & Biobío & 0.00 & 0.17 & 3.33 & 0.00 & 0.00 & 0.00 & 2.83 & 0.00 & 0.00 & 0.50 & 0.50 & 1.06 & 0.00 & 0.00 & 0.41 \\
\hline Hacienda San Lorenzo, Quilleco & Biobío & 0.00 & 2.44 & 2.67 & 0.00 & 0.00 & 0.67 & 1.33 & 0.00 & 0.00 & 0.00 & 0.00 & 0.00 & 0.00 & 0.00 & 0.00 \\
\hline Alto las Viñas, Los Ángeles & Biobío & 0.00 & 0.00 & 8.67 & 0.00 & 0.00 & 0.00 & 2.67 & 0.00 & 0.33 & 0.00 & 0.67 & 0.00 & 0.00 & 0.00 & 0.00 \\
\hline Antihuala, Los Álamos & Biobío & 0.00 & 1.00 & 0.33 & 0.00 & 0.00 & 0.00 & 1.67 & 0.00 & 0.00 & 0.33 & 2.67 & 0.00 & 0.00 & 0.00 & 0.00 \\
\hline La Curva, Cañete & Araucanía & 0.00 & 0.17 & 1.00 & 0.00 & 0.00 & 0.00 & 0.33 & 0.00 & 0.00 & 1.33 & 0.00 & 0.00 & 0.00 & 0.00 & 0.00 \\
\hline Llacolén, Contulmo & Biobío & 0.00 & 0.59 & 1.04 & 0.00 & 0.00 & 0.00 & 3.26 & 0.00 & 0.00 & 0.00 & 0.00 & 0.00 & 0.00 & 0.00 & 0.00 \\
\hline Llanquén, Lonquimay & Araucanía & 0.00 & 2.00 & 0.00 & 0.00 & 0.00 & 1.67 & 1.33 & 0.00 & 0.00 & 0.00 & 0.00 & 2.25 & 0.00 & 0.00 & 0.60 \\
\hline
\end{tabular}


Table 1. Cont.

\begin{tabular}{|c|c|c|c|c|c|c|c|c|c|c|c|c|c|c|c|c|}
\hline \multirow[b]{2}{*}{ Locality, County } & \multirow[b]{2}{*}{$\begin{array}{l}\text { Administrative } \\
\text { Region }\end{array}$} & \multicolumn{11}{|c|}{ Relative Abundance } & \multicolumn{4}{|c|}{ Relative Seropositivity } \\
\hline & & Al & Ah & Ao & As & Am & Lm & Ol & Pd & $\mathrm{Mm}$ & $\mathbf{R n}$ & $\mathbf{R r}$ & Ol & Ah & Ao & Total \\
\hline Tirúa, Tirúa & Biobío & 0.00 & 0.00 & 1.11 & 0.00 & 0.00 & 0.00 & 1.11 & 0.00 & 0.00 & 0.00 & 0.00 & 0.00 & 0.00 & 0.00 & 0.00 \\
\hline Lautaro, Lautaro & Araucanía & 0.00 & 0.00 & 2.00 & 0.00 & 0.00 & 0.00 & 0.33 & 0.00 & 0.67 & 0.00 & 0.00 & 0.00 & 0.00 & 0.00 & 0.00 \\
\hline Fundo La Aguada, Gorbea & Araucanía & 0.00 & 1.56 & 0.44 & 0.00 & 0.00 & 0.00 & 0.00 & 0.00 & 0.00 & 0.22 & 0.22 & 0.00 & 1.29 & 0.00 & 0.82 \\
\hline Lago Colico, Cunco & Araucanía & 0.00 & 2.19 & 1.09 & 0.00 & 0.00 & 0.00 & 12.57 & 0.00 & 0.00 & 0.55 & 1.09 & 0.08 & 0.00 & 0.00 & 0.06 \\
\hline Boroa Norte, Toltén & Araucanía & 0.00 & 0.00 & 0.32 & 0.00 & 0.00 & 0.00 & 6.13 & 0.00 & 0.00 & 0.32 & 3.55 & 0.33 & 0.00 & 0.00 & 0.19 \\
\hline Loncoche, Loncoche & Araucanía & 0.00 & 2.08 & 1.67 & 0.00 & 0.00 & 0.00 & 2.50 & 0.00 & 0.00 & 0.00 & 0.42 & 0.00 & 0.00 & 0.00 & 0.00 \\
\hline Llancahue Alto, Panguipulli & Los Ríos & 0.00 & 3.83 & 0.00 & 0.00 & 0.00 & 0.17 & 0.00 & 0.00 & 0.00 & 0.00 & 0.00 & 0.00 & 0.78 & 0.00 & 0.75 \\
\hline Fundo Miraflores, Lanco & Los Ríos & 0.00 & 0.74 & 1.04 & 0.00 & 0.00 & 0.00 & 8.74 & 0.00 & 0.00 & 0.00 & 0.00 & 0.69 & 1.35 & 0.00 & 0.67 \\
\hline Ñancul, Panguipulli & Los Ríos & 0.00 & 0.00 & 3.33 & 0.00 & 0.00 & 0.00 & 17.50 & 0.00 & 0.00 & 0.83 & 1.67 & 0.00 & 0.00 & 0.00 & 0.00 \\
\hline Huellelhue-Pishuinco, Valdivia & Los Ríos & 0.00 & 1.63 & 6.54 & 0.00 & 0.00 & 0.00 & 0.65 & 0.00 & 0.00 & 0.00 & 0.33 & 0.00 & 0.00 & 0.00 & 0.00 \\
\hline Campamento Vientos del Sur, Valdivia & Los Ríos & 0.00 & 1.00 & 1.00 & 0.00 & 0.00 & 0.00 & 2.33 & 0.00 & 0.00 & 0.33 & 1.00 & 0.43 & 0.00 & 0.00 & 0.18 \\
\hline San Carlos, Corral & Los Ríos & 0.00 & 0.00 & 3.68 & 0.00 & 0.00 & 0.00 & 1.47 & 0.00 & 0.00 & 0.74 & 0.74 & 0.00 & 0.00 & 0.00 & 0.00 \\
\hline Playa San Julián, Corral & Los Ríos & 0.00 & 7.27 & 1.52 & 0.00 & 0.00 & 0.00 & 0.61 & 0.00 & 0.00 & 0.61 & 0.30 & 0.00 & 0.14 & 0.00 & 0.10 \\
\hline Fundo Futangue, Lago Ranco & Los Ríos & 0.00 & 3.30 & 2.20 & 0.73 & 0.00 & 0.00 & 3.30 & 0.00 & 0.00 & 0.00 & 0.00 & 0.00 & 0.00 & 0.00 & 0.00 \\
\hline Las Quemas, Osorno & Los Lagos & 0.00 & 0.88 & 3.53 & 0.00 & 0.29 & 0.59 & 0.00 & 0.00 & 0.00 & 0.59 & 0.00 & 0.00 & 1.13 & 0.57 & 0.51 \\
\hline Ñilque, Puyehue & Los Lagos & 0.00 & 2.96 & 1.85 & 0.00 & 0.00 & 0.00 & 5.56 & 0.00 & 0.00 & 0.37 & 0.00 & 0.00 & 0.34 & 0.00 & 0.09 \\
\hline El Encanto, Puyehue & Los Lagos & 0.00 & 2.04 & 1.67 & 0.00 & 1.11 & 0.00 & 4.07 & 0.00 & 0.00 & 0.37 & 0.37 & 0.00 & 0.00 & 0.60 & 0.10 \\
\hline Rupanquito, Osorno & Los Lagos & 0.00 & 0.97 & 3.23 & 0.00 & 0.00 & 0.00 & 8.39 & 0.00 & 0.32 & 0.32 & 0.65 & 0.24 & 0.00 & 0.00 & 0.14 \\
\hline El Cabrito, Puerto Octay & Los Lagos & 0.00 & 1.82 & 2.42 & 0.00 & 0.00 & 0.00 & 6.06 & 0.00 & 0.00 & 0.30 & 0.00 & 0.17 & 0.55 & 0.00 & 0.19 \\
\hline Peulla, Puerto Varas & Los Lagos & 0.00 & 2.22 & 0.83 & 0.00 & 0.00 & 0.00 & 0.56 & 0.00 & 0.00 & 0.00 & 0.83 & 0.00 & 0.00 & 0.00 & 0.00 \\
\hline Fundo Pichi-Juan, Puerto Varas & Los Lagos & 0.00 & 0.17 & 1.83 & 0.00 & 0.17 & 0.17 & 5.33 & 0.00 & 0.00 & 0.00 & 0.00 & 0.00 & 0.00 & 0.00 & 0.00 \\
\hline Las Quemas, Puerto Montt & Los Lagos & 0.00 & 0.13 & 1.43 & 0.00 & 0.00 & 0.13 & 0.39 & 0.00 & 0.00 & 0.00 & 0.13 & 0.00 & 0.00 & 0.00 & 0.00 \\
\hline Caleta Rollizo, Cochamó & Los Lagos & 0.00 & 0.25 & 3.98 & 0.00 & 0.00 & 0.00 & 1.99 & 0.00 & 0.00 & 0.00 & 0.00 & 0.00 & 4.02 & 0.00 & 0.16 \\
\hline Paso El León, Cochamó & Los Lagos & 0.00 & 4.00 & 1.00 & 0.00 & 0.00 & 0.00 & 12.33 & 0.00 & 0.00 & 0.00 & 0.00 & 0.08 & 0.00 & 0.00 & 0.06 \\
\hline Parque Nacional Chiloé, Chonchi & Los Lagos & 0.00 & 0.00 & 4.30 & 1.04 & 0.00 & 0.00 & 1.04 & 0.00 & 0.00 & 0.15 & 0.00 & 0.00 & 0.00 & 0.00 & 0.00 \\
\hline Cerro Negro, Coyhaique & Aysén & 0.00 & 0.56 & 0.28 & 0.00 & 0.00 & 0.00 & 0.56 & 0.00 & 0.00 & 0.00 & 0.00 & 0.00 & 0.00 & 0.00 & 0.00 \\
\hline
\end{tabular}

longicaudatus, $\mathrm{Pd}=$ Phyllotis darwini, $\mathrm{Mm}=$ Mus musculus, $\mathrm{Rn}=$ Rattus norvegicus, $\mathrm{Rr}=$ Rattus rattus. 


\subsection{Intraspecific Seropositivity}

A total of 58 specimens were found positive for antibodies against the ANDV (seropositives) from 30 localities (Figure 1). Of the 631 O. longicaudatus captured, 41 were seropositive from 22 localities (Figure 2A), with an intraspecific seroprevalence of 6.5\%. For A. hirta, 234 individuals were captured, 12 were seropositive from nine localities (Figure 2B) with an intraspecific seroprevalence of 5.13\%. For A. olivacea, 636 individuals were captured, with five seropositives from four localities (Figure 2C) and an intraspecific seroprevalence of $0.79 \%$. All seropositive $O$. longicaudatus were adults, including 32 males and nine females. For $A$. hirta, of the 12 seropositives, seven were adult males, four adult females and one juvenile male. For A. olivacea, five were seropositive, including three adult males, one juvenile male and one juvenile female.

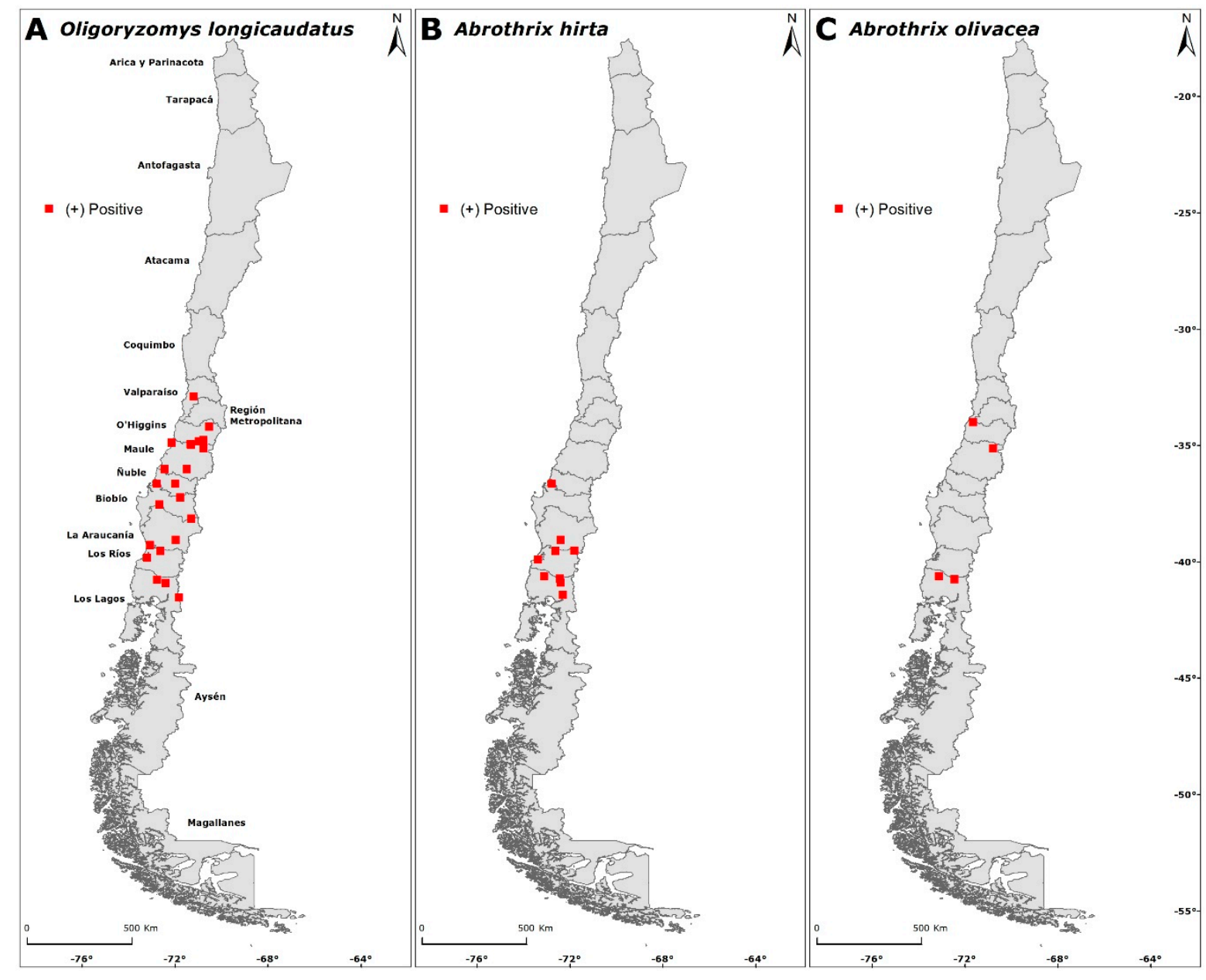

Figure 2. Distribution of rodents with anti-ANDV antibodies in areas associated with human hantavirus cases for O. longicaudatus, A. hirta and A. olivacea during the nineteen-year study in Chile.

Among sites, the highest relative seropositivity for $O$. longicaudatus was reported in Las Peñas 2002, San Fernando, O'Higgins region and Los Queñes, Romeral, Maule region (3.6), and the lowest in Paso El León, Cochamó, Los Lagos region and Colico, Cunco, Araucanía region (0.08). A. hirta showed the highest relative seropositivity in Caleta Rollizo, Cochamó, Los Lagos region (4.02) and the lowest in Playa San Julián, Corral, Los Ríos region (0.14). A. olivacea showed the highest relative seropositivity in Los Queñes, Romeral, Maule region (3.6) and Ucúquer, Litueche, O'Higgins region (0.32).

Of the 631 O. longicaudatus captured, 127 had wounds, of which 26 (20.5\%) were seropositive to ANDV, including 23 adult males and three adult females. Of the 101 seronegatives with wounds, 90 were adults and 11 juveniles; 55 were males and 46 females. Of the 234 A. hirta captured, 67 specimens 
showed wounds, including five (7.5\%) seropositive adults (three males and two females). For the 62 seronegative $A$. hirta with wounds, 51 were adults and 11 were juveniles, and 45 were males and 17 females. Of the $636 \mathrm{~A}$. olivacea captured, 91 specimens had wounds, including one seropositive juvenile female and one seropositive adult male. Among the 89 seronegative A. olivacea with wounds, there were 82 adults and seven juveniles, and 59 males and 30 females.

\subsection{Association Between Seropositives and Biological Traits}

By using contingency tables, we analyzed the relationships between species (O. longicaudatus, A. hirta and A. olivacea) versus sex, wounds and age (Table 2) to determine the differences among seropositives. For $O$. longicaudatus, seropositivity was significantly higher in males than in females $(p=0.0028)$, in wounded $(p<0.0001)$ specimens and in adults $(p=0.0066)$. For $A$. hirta and A. olivacea, neither sex, wounds nor age were associated with seropositivity.

Table 2. Results of contingency test of three seropositive species versus sex, age and wounds.

\begin{tabular}{|c|c|c|c|c|c|c|c|c|c|c|c|c|c|c|c|}
\hline \multicolumn{2}{|c|}{ Species/Trait } & \multicolumn{6}{|c|}{ O. longicaudatus } & \multicolumn{4}{|c|}{ A. hirta } & \multicolumn{4}{|c|}{ A. olivacea } \\
\hline & & $(+)$ & $(-)$ & Sum & chi-Square & df & $p$ & $(+)$ & $(-)$ & Sum & $p$ & $(+)$ & $(-)$ & Sum & $p$ \\
\hline \multirow{2}{*}{ Sex } & Male & 32 & 319 & 351 & 8.93 & 1 & 0.0028 & 8 & 129 & 137 & 0.394 & 4 & 376 & 380 & 0.419 \\
\hline & Sum & 41 & 590 & 631 & & & & 12 & 222 & 234 & & 5 & 631 & 636 & \\
\hline \multirow[b]{2}{*}{ Age } & Adult & 41 & 499 & 540 & 7.39 & 1 & 0.0066 & 11 & 187 & 198 & 0.423 & 3 & 556 & 559 & 0.114 \\
\hline & Juvenile & 0 & 91 & 91 & & & & 1 & 35 & 36 & & 2 & 75 & 77 & \\
\hline \multirow{3}{*}{ Wound } & Wounds & 26 & 101 & 127 & 51.11 & 1 & $<0.0001$ & 5 & 62 & 67 & 0.236 & 2 & 89 & 91 & 0.152 \\
\hline & Without wounds & 15 & 489 & 504 & & & & 7 & 160 & 167 & & 3 & 542 & 545 & \\
\hline & Sum & 41 & 590 & 631 & & & & 12 & 222 & 234 & & 5 & 631 & 636 & \\
\hline
\end{tabular}

Logistic regression (Figure 3A) using serostatus and weight showed that for O. longicaudatus, there is an increase in the probability to be seropositive for individuals of higher weight. Individuals of at least $60 \mathrm{~g}$ in weight have $80 \%$ or higher probability to be seropositive. This probability value drastically decreases with individuals of lower weight (i.e., an individual of $40 \mathrm{~g}$ has a $21 \%$ probability to be seropositive). Contrasting data were found for A. hirta (Figure 3B). In spite of the trend in which the higher the weight higher chances to be seropositive, our study showed that an individual of $70 \mathrm{~g}$ has a probability lower than $20 \%$ to be seropositive.
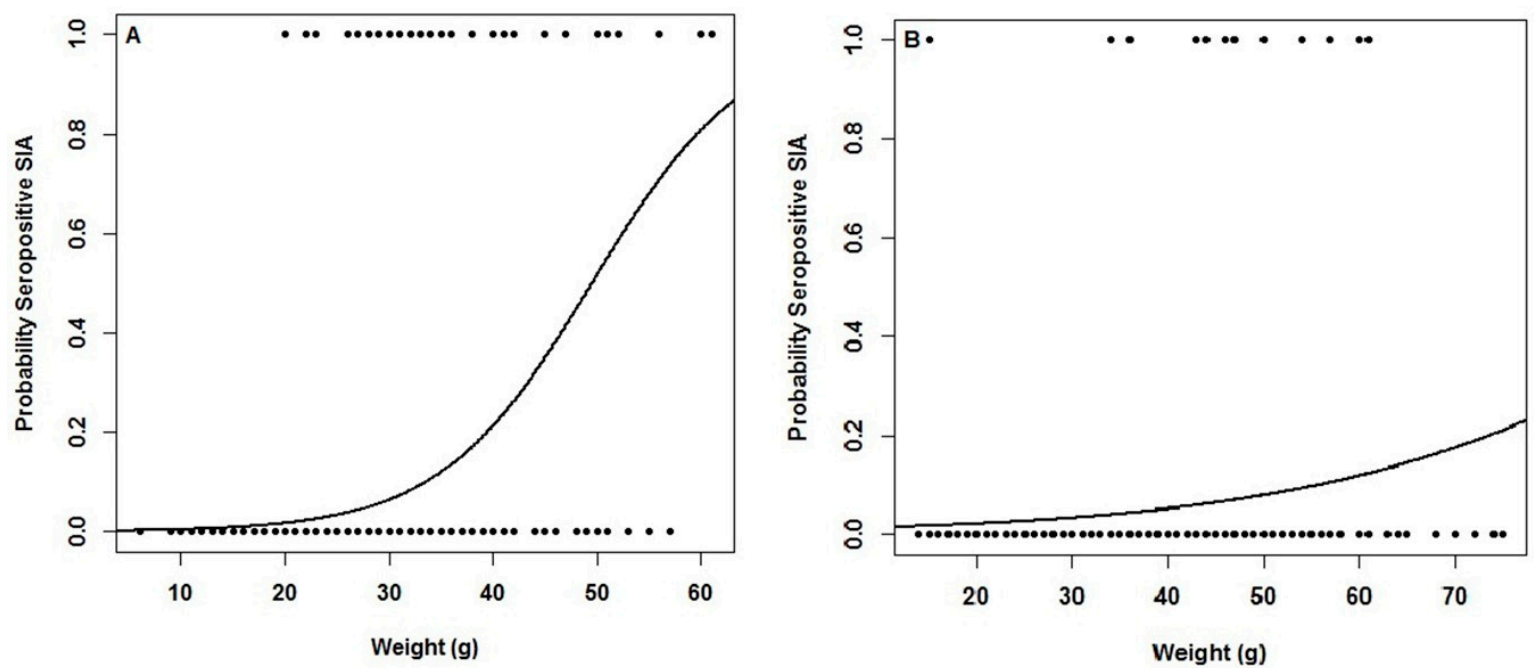

Figure 3. Logistic regression including seropositives for anti-ANDV antibodies versus weight of each capture specimen in sites associated with human hantavirus cases in Chile for (A) O. longicaudatus, and (B) A. hirta. 


\subsection{Human HCPS Cases}

During the 19-year study period, 1060 human cases were confirmed as positive for HCPS in the 11 administrative regions in the southcentral regions of Chile sampled in this study (information available from the web page of Ministerio de Salud de Chile, http//:epi.minsal.cl). Rodent relative seropositivity was highest in the Maule region, whereas rates approaching 1.5\% were found in O'Higgins, Araucanía, Biobío, Los Ríos and Los Lagos regions. We did not detect seropositive rodents in Coquimbo and Aysén regions (Figure 4), probably due to a bias in the low sampling effort (one sampling in each region). No seropositive rodents were also found in peridomestic sites in the Metropolitan region despite sampling in 14 localities (Table 1) and registering 54 HCPS cases. During the sampling period (2000-2018), the higher number of HCPS cases was registered in Los Lagos region (184 cases), and the lowest in Coquimbo (one case). However, when standardized by people inhabiting in rural areas, human hantavirus cases were notably higher in Aysén region, followed by Los Ríos, Nuble and Los Lagos (Figure 4).

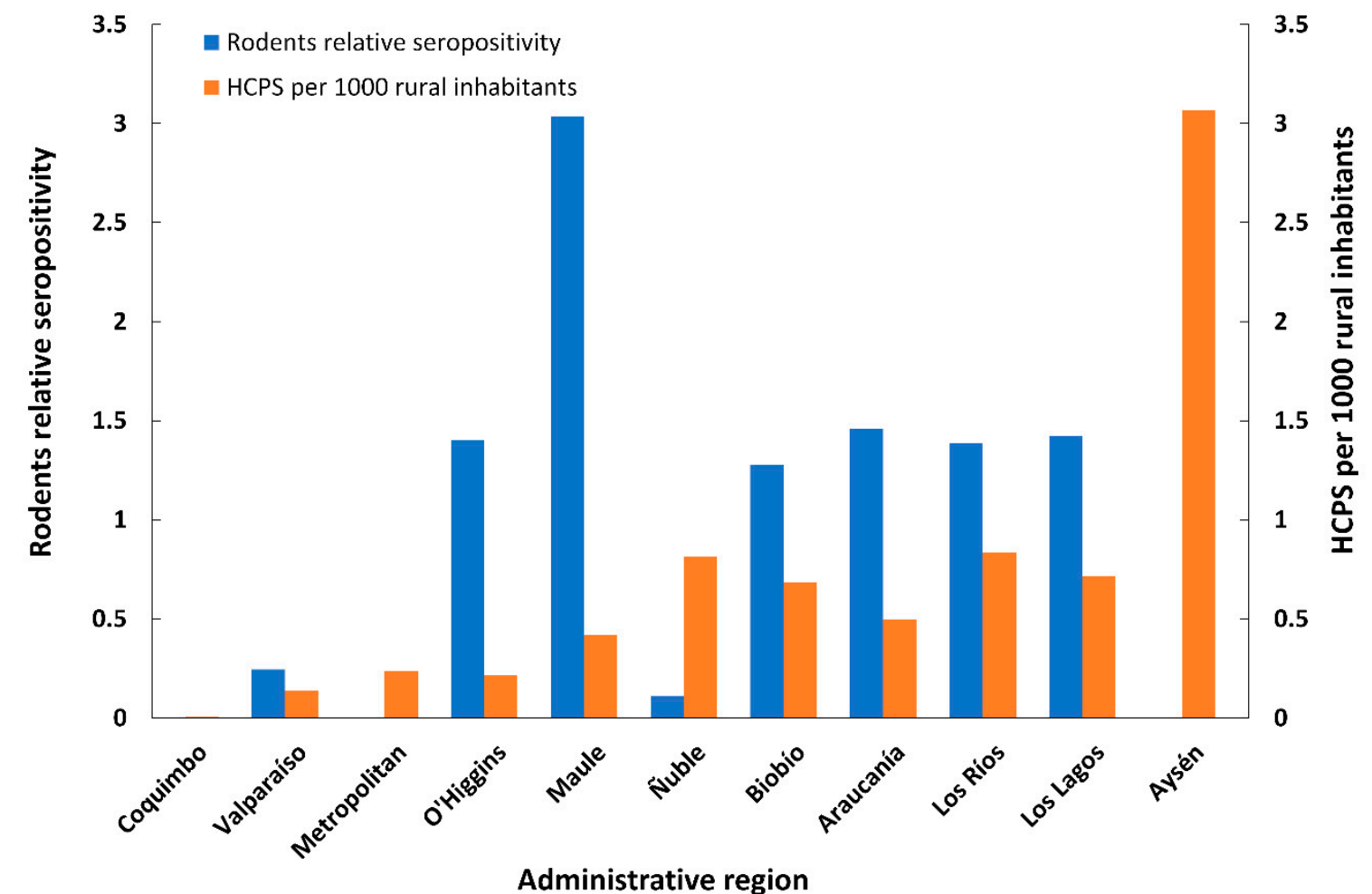

Figure 4. Rodents' relative seropositivity in sites associated with human Hantavirus cases, and human hantavirus cases per 1000 rural inhabitants across the 11 administrative sampled regions in Chile. Regions are ordered from north (left) to south (right).

\section{Discussion}

The extension of the geographical distribution of a zoonotic disease is intrinsically linked to the niche of its host. How hosts interact with human activity and settlements, and the degree of pathogen transmission among host and human populations, will determine the scale of infections that will produce the disease in humans. Hantaviruses are known to be transmitted horizontally [21,40], therefore ecological interactions are key to understanding the spread of the virus among reservoir populations. It is also known that a virus may be harbored by two or more species, with higher opportunities for host switch particularly for sympatric species [41-43]. Our study shows the importance of conducting long-term studies that cover a large part of the distribution of a pathogen and its hosts, allowing us to infer patterns of infection and the scale of a host's epidemiologic importance. 
The eleven rodent species analyzed during the nineteen years of sampling in areas associated with human hantavirus cases showed different patterns of abundance in Chile. The highest relative abundance within each sampling site for O. longicaudatus was found in the Los Ríos region, for A. olivacea and A. hirta in the Biobío region, for A. longipilis and Mus musculus in the Valparaíso region, for A. sanborni in the Los Lagos region, for L. micropus and R. rattus in the Araucanía region and for P. darwini and R. norvegicus in the $\mathrm{O}^{\prime}$ Higgins region (Table 1, Appendix A). The geographic heterogeneity among rodent abundances is expected and linked to their ecology. For example, despite the wide distribution of $O$. longicaudatus in Chile (from the southern of Atacama desert to Patagonia), the primary habitat of this species occurs in mesic areas that are more prominent between $35-50^{\circ} \mathrm{S}$ in the Valdivian and Patagonian rain forest ecoregions [36,44]. Our study supports this inference, as more O. longicaudatus were captured in localities of Biobío, Araucanía, Los Ríos and Los Lagos regions that fall within the Valdivian rain forests (Appendix A). To understand the scale of the relation between abundance of host and prevalence of the pathogen, we compared the host relative abundance and pathogen infection measured as relative seropositivity. Comparing sampling localities, we found heterogeneous results (Table 1). For example, high abundance of O. longicaudatus and absence of seropositives were registered in Vilumanque (Concepción), and Nancul (Panguipulli), contrasting with localities with low abundance of this species and high seropositivity (e.g., Las Peñas, San Fernando, O'Higgins and La Palma, Valparaíso). This expected pattern was also reported by several studies [20,30], emphasizing the uncertainty of sampling the host carrying the virus despite the epidemiological and ecological analyses to determine the most probable site of human infection [45]. We acknowledge that our estimations of seropositivity might be biased due to an error associated to false positives and/or negatives determined by the SIA method [46]. However, we expect a low error in this parameter [46,47].

In the present study, the seroprevalence of $3.14 \%$ for all small mammals and $3.63 \%$ for sigmodontine rodents was higher to that reported previously in Chile [20,30,48], an expected result due to our sampling scheme linked to recent confirmed HCPS cases. The variation of total seroprevalence reported in the Americas includes similar percentages to those of our study, such as in Argentina (1.5\% in the north, $2.6 \%$ in the center and 5.4\% in the south) [49], Brazil (2.1\%) [50] and North America (average 5\%) [51], but differs from others with higher rates such as Panama, Mexico and United States of America [52-55].

For O. longicaudatus, we found an intraspecific seroprevalence of $6.5 \%$, a value within the range of other studies in Chile reporting seroprevalences of 10.4\% [20] and 2.5\% [30]. The heterogeneity observed in the seroprevalence of rodent populations depends on several factors impacting the ecological dynamics of the host and the virus, such as climate [56], landscape structure [52,57], density-based and/or frequency-based dependence [58-60], dilution effect [61], viral recrudescence [47] and habitat disturbance [26,62]. Our sampling scheme also allowed us to show new evidence for the prevalence of antibody against ANDV in Chile in species other than the major host. We found an intraspecific seroprevalence of $5.13 \%$ for $A$. hirta and $0.79 \%$ for $A$. olivacea. For many years, A. longipilis was identified as the second species with higher seroprevalence in Chile. However, new taxonomic rearrangements show that those results were skewed, because the results should be reassigned to $A$. hirta [33,42]. Taking this into account, the seroprevalence for $A$. hirta ranges from $9.3 \%$ in Los Ríos region [63] to 1.84\% in Los Lagos region [21], representing the highest seroprevalence for hantavirus in Chile after the main reservoir O. longicaudatus. Compared with O. longicaudatus (6.5\%), our seroprevalence data for $A$. hirta $(5.13 \%)$ acquires new relevance, particularly in understanding its role in maintaining the virus in nature, or potentially as host of a new lineage of hantavirus of unknown pathogenicity $[5,36,64]$. Based on ours and all previous published data, no $A$. longipilis have been found seropositive to ANDV in Chile. For A. olivacea, the most abundant species captured, an intraspecific seroprevalence of 7.5\% and $0.73 \%$ has been reported in Aysén region [29,65,66], 2.2\% in Los Lagos region [66] and 1.5\% in Chubut, Argentina [67]. Hantaviruses are capable of infecting multiple host species [5,45], and host-switching events have been reported between species of the same and different families and also separate orders [68]. Cross-species transmission is more likely to occur among sympatric and evolutionary related species, so the study of their ecological interactions is key to 
understand the processes leading to species jumps and emergence of outbreaks. ANDV experimental transmission was demonstrated from O. longicaudatus to A. olivacea [21], but the epidemiological importance of $A$. hirta and A. olivacea remains unclear [42]. We highlight that our study is one of the few long-term involving only areas associated with human hantavirus cases, therefore the seroprevalences may also differ from others covering alternative sampling designs.

The relationships between species (O. longicaudatus, $A$. hirta and $A$. olivacea) versus sex, wounds and age have been frequently studied to infer major determinants of spread and maintenance of viruses in nature. It has been proposed that most of seropositive O. longicaudatus are adult males, which was evaluated in this study. A positive relationship between weight and seropositivity in O. longicaudatus suggests that adults are more likely to be infected than juveniles. Although we did not search for viral RNA in seronegative rodents, there it might be a proportion of rodents that are viremic and without antibodies that might be excreting the virus into the environment. We found that adult males (32/41 of positives) are more likely to be seropositive than females (9/41 of positives; Table 2), a result congruent with studies in several wild reservoirs [20,67,69-73]. Our logistic regression (Figure 2) also shows that O. longicaudatus weighing $60 \mathrm{~g}$ or more were more likely ( $80 \%)$ to be infected with ANDV. A slightly different analysis in the same species in Argentina showed that individuals not injured of $50 \mathrm{~g}$ (approx.) and those of $43 \mathrm{~g}$ (approx.) with wounds, have a probability of 0.80 to be infected with the virus [73]. Our analysis was performed including both wounded and non-wounded O. longicaudatus from all ages. We chose this approach because the role of wounds in hantavirus transmission is still in debate (see below). Adults seem to be more likely to contract the virus because transmission of the virus requires a prolonged period of exposure [74]. O. longicaudatus adult females were less likely to be seropositive, suggesting that adult males may have a major role in maintaining the virus transmission in nature. However, the frequency of seropositive females found across several studies is evidence that they may play a more important role than the one currently recognized. Space use and social mating system may contribute to reveal the factors maintaining the virus in wild populations and explaining sex differences of infected hosts [75]. However, viral transmission through aggressive encounters including frequent bites among adult males have been proposed as major hypothesis to explain sex differences [56,76-78].

We found 127 O. longicaudatus with wounds of which 26 were seropositive (23 males and three females). Our results provide evidence that $O$. longicaudatus adult males with wounds would be more likely to be seropositive (Table 2). An association between wounds and seropositive status suggests that antagonistic encounters between reproductive individuals would be a mechanism of transmission between host populations [79-81]. Interestingly, the probability that an O. longicaudatus adult male in Argentina is seropositive is five times higher in injured individuals [73]. The previous study showed that adult males with wounds with a body-mass greater than $44 \mathrm{~g}$ have a probability of 0.84 to be seropositive, while individuals with wounds and a body-mass less than $30 \mathrm{~g}$ have a probability of being seropositive of 0.2 . Although wounds seem to be the mechanism for intraspecific transmission of hantaviruses, a few studies have found different results. For example, in Peromyscus maniculatus, the prevalence seemed to reach a peak much earlier in individuals with wounds, possibly indicating that aggression is not the only mechanism of transmission of Sin Nombre orthohantavirus among deer mice [69]. The relationship between hosts with wounds and seropositivity might also be a consequence of the infection [78,80,82-84], or it might be related to a greater population density of the reservoir, resulting in viral transmission caused by the greater environmental contamination rather than by aggression among rodents [80]. No relationship between infection and individuals with wounds was found among the O. longicaudatus in southern Argentina [67]. There are also social behaviors such as identification, mounting, smelling and persecution that favor physical unaggressive contact among individuals [85]. Field experiments in O. longicaudatus do not support a relationship between the presence of wounds and the transmission of ANDV, indicating that other factors such as grooming or aerosol transmission may be playing a major role for efficient viral transmission [21].

Unlike O. longicaudatus, seropositive juveniles were identified in the two species of Abrothrix. For A. hirta, one juvenile male out of 12 was infected. Three adult males and two juveniles (one male and 
one female) were seropositive for A. olivacea. The number of Abrothrix infected with hantavirus is frequently low or absent compared to that of sympatric $O$. longicaudatus, both in areas with or without human cases $[20,30,86]$. In addition to global seroprevalence and sex, we tested if wounds were related to infected Abrothrix. We found no association in both species of Abrothrix (5/12 seropositives of $A$. hirta and 2/5 for $A$. olivacea with wounds; Table 2), similar to a previous study [63]. Despite some efforts to study viral ecology of coexisting species with the main reservoir, the epidemiological relevance of Abrothrix is still unknown [21,29,30,42,87].

The ecological properties of host and vectors are influenced by environmental features [88], which may be strong determinants in the transmission of the virus to humans across different spatial and temporal scales $[36,89]$. The wide latitudinal range of our samplings ranges from a Mediterranean heterogeneous vegetation mosaic to a mixed evergreen-deciduous temperate and Patagonian forest $\left(30^{\circ} 30^{\prime} \mathrm{S}-45^{\circ} 30^{\prime} \mathrm{S}\right)[90,91]$. These areas are characterized by contrasting landscapes resulting in strong differences in population structure of O. longicaudatus [92,93], A. hirta [94] and A. olivacea [95]. Variability in the population dynamic of $O$. longicaudatus populations across their latitudinal range in Chile may impact transmission and infection rates of ANDV in rodent hosts [36]. Therefore, humans may be differentially exposed to viral infection. A variety of studies reported high differences in seroprevalence of $\mathrm{O}$. longicaudatus in Chile across administrative regions, ranging from $23 \%$ for the O'Higgins region [66], 12.74\% and 12,7\% for the Aysén region [29,65], 13.51\% in the Los Ríos and Los Lagos regions [63] to $1.44 \%$ in the Magallanes region [96]. Interestingly, we found that rodents' relative seropositivity was higher in the Maule region (around $34-36^{\circ} \mathrm{S}$ ). This region is within the Mediterranean ecoregion, which showed the highest relative seropositivity in Chile [36]. Complex interacting determinants may be involved in explaining this result $[97,98]$. Landscape structure and hosts' responses to disturbances and habitat modifications may strongly influence reservoir populations [99] and infectious disease dynamics [98]. For example, hosts may become the dominant species in degraded ecosystems [100], and agroecosystems may play a relevant but still unknown role in harboring infected hosts, and therefore in the transmission of virus to humans [101]. Agriculture and habitat modification, features that characterize the Maule region, are also found in several other regions where we detected high seroprevalence (Figure 4). These inferences acquire more relevance when small mammal studies are linked to areas where humans are at higher risk of contracting the pathogen such as domestic/peridomestic settings $[26,49,102]$. Similar values of relative seropositivity were found across O’Higgins, Araucanía, Biobío, Los Ríos and Los Lagos regions. We did not detect seropositive rodents in Coquimbo and Aysén regions (Figure 4), probably due to the low comparative sampling effort (one sampling locality in each region). No seropositive rodents were found in peridomestic sites in the Metropolitan region despite sampling in 14 localities (Table 1) and registering 54 confirmed HCPS cases. Whether these cases contracted the infection outside of this region or we were unable to detect seropositives due to our sampling scheme remains to be elucidated. We observed a trend of finding an increased number of HCPS cases from north to south (Figure 4). The high number of reported HCPS cases found the Aysén region was likely influenced by the approach we used (HCPS cases/1000 rural inhabitants). In fact, rural inhabitants in Aysén were significantly lower compared to the other regions reported in this study; also 61 HCPS cases were confirmed in the Aysén region during the study period while a higher number of cases were reported for Los Lagos $(N=184)$, Araucanía $(N=158)$ and Biobío $(N=156)$ regions. Despite the differences in the sampling efforts across administrative regions, the geographic and temporal span of our study highlights the heterogeneity of HCPS cases and the spatial fluctuations of seropositive hosts. Consequently, these data emphasize that integrating ecological understanding of host and pathogens, spatial and temporal surveillance, epidemiology and public health agencies is fundamental to i) understanding the driving processes that ultimately lead to the transmission of virus to humans and ii) successfully designing policies and campaigns to prevent the infection from zoonotic diseases [26,52,103,104]. 


\section{Conclusions}

Our study assessed how ecology and geography influence host and viral dynamics in areas associated with HCPS cases in Chile. We confirmed the major role of O. longicaudatus as a reservoir of ANDV in Chile and the significance of adult males in maintenance and transmission of the virus in nature. Our results indirectly show that wounds might play a significant role in the intraspecific transmission of the virus, which coupled with alternative routes previously reported, suggest that to fully understand the host-viral transmission, further investigation is required on social and behavior interactions of rodents. We highlighted that the epidemiological importance of $A$. hirta and A. olivacea in maintaining and/or transmitting the virus among wild populations and to humans remains unclear.

The high variation in rodents' abundance and seroprevalence across a wide geography, emphasizes the need for i) understanding the drivers that determine the dynamic of fluctuating populations of reservoirs, ii) determining the role of other interacting species for the viral spread and iii) integrating efforts from different disciplines to more accurately determine transmission rates of pathogens within host populations, host switch and ultimately to humans. Elucidating these patterns is critical to prevent future zoonotic outbreaks by implementing effective intervention strategies.

Author Contributions: F.T.P., R.E.P., M.F., P.A.V., C.V., P.A.M. and G.J.M. conceived and designed the experiments; F.T.P., D.B.B., C.M., A.P. and C.P. performed the experiments; F.T.P., D.B.B., R.E.P., C.M., M.F., P.A.V., A.P., and C.P. analyzed the data; C.M., M.F., A.P., C.P., R.E.P., P.A.V., C.V., P.A.M. and G.J.M. contributed reagents/materials/analysis tools; F.T.P., D.B.B. and R.E.P. wrote the paper; C.M., M.F., P.A.V., C.V., A.P., P.A.M., G.J.M. reviewed and edited the manuscript.

Funding: Financial support was provided by the Fogarty International Center Research Grant \# D43 TW007131, the NIH-ICIDR Chilean Hantavirus Grant 1 U19 AI45452-01, FONDECYT 1171280 and 1110664 (F.T.P.), 1130467 and 1170761 (R.E.P.), 3180237 (D.B.B.), 1161197 (M.F.), 1161447 (C.V.), and CONICYT-PIA ACT1408 (M.F., F.T.P.).

Acknowledgments: We thank Ministry of Health of Chile and local health services for providing information on sampling sites where HCPS cases occurred, and the Servicio Agrícola y Ganadero (SAG) and Corporación Nacional Forestal (CONAF) for trapping permits. We also thank the hantavirus field crew.

Conflicts of Interest: The authors declare no conflict of interest. 


\section{Appendix A}

Table A1. Relative abundance, relative seropositivity and seropositives to ANDV by locality and administrative regions of rodent sampled species.

\begin{tabular}{|c|c|c|c|c|c|c|c|c|c|c|c|c|c|c|c|c|c|c|c|c|c|c|c|}
\hline \multirow[b]{2}{*}{ Locality, County } & \multirow[b]{2}{*}{ Latitude } & \multirow[b]{2}{*}{ Longitude } & \multirow[b]{2}{*}{$\begin{array}{l}\text { Administrative } \\
\text { Region }\end{array}$} & \multirow[b]{2}{*}{ Total Traps } & \multirow[b]{2}{*}{ Year } & \multicolumn{11}{|c|}{ Relative Abundance } & \multicolumn{3}{|c|}{ Seropositives } & \multicolumn{4}{|c|}{ Relative Seropositivity } \\
\hline & & & & & & Al & Ah & Ao & As & Am & $\mathrm{Lm}$ & Ol & $\mathbf{P d}$ & $\mathrm{Mm}$ & $\mathbf{R n}$ & $\mathrm{Rr}$ & Ol & Ah & Ao & Ol & Ah & Ao & Total \\
\hline Chiñigue, Ovalle & -30.513 & -71.102 & Coquimbo & 300 & 2006 & 1.00 & 0.00 & 2.33 & 0.00 & 0.00 & 0.00 & 0.00 & 0.00 & 0.67 & 0.67 & 0.33 & 0 & 0 & 0 & 0.00 & 0.00 & 0.00 & 0.00 \\
\hline Fundo Chuico Blanco, Hijuelas & -32.812 & -71.089 & Valparaíso & 270 & 2002 & 0.00 & 0.00 & 0.00 & 0.00 & 0.00 & 0.00 & 0.37 & 0.00 & 0.00 & 1.11 & 0.00 & 0 & 0 & 0 & 0.00 & 0.00 & 0.00 & 0.00 \\
\hline Llaillay, Llaillay & -32.854 & -70.918 & Valparaíso & 237 & 2001 & 0.00 & 0.00 & 0.42 & 0.00 & 0.00 & 0.00 & 0.00 & 0.00 & 2.53 & 0.42 & 0.00 & 0 & 0 & 0 & 0.00 & 0.00 & 0.00 & 0.00 \\
\hline Lo Mardones, Quillota & -32.870 & -71.221 & Valparaíso & 630 & 2016 & 0.00 & 0.00 & 2.06 & 0.00 & 0.00 & 0.00 & 0.48 & 0.00 & 0.63 & 0.95 & 0.00 & 0 & 0 & 0 & 0.00 & 0.00 & 0.00 & 0.00 \\
\hline La Palma, Quillota & -32.908 & -71.206 & Valparaíso & 600 & 2013 & 0.00 & 0.00 & 0.33 & 0.00 & 0.00 & 0.00 & 0.33 & 0.00 & 0.00 & 0.83 & 0.17 & 1 & 0 & 0 & 3.00 & 0.00 & 0.00 & 0.60 \\
\hline Población Prat, Villa Alemana & -33.070 & -71.357 & Valparaíso & 300 & 2001 & 0.00 & 0.00 & 4.67 & 0.00 & 0.00 & 0.00 & 0.00 & 0.00 & 1.00 & 0.00 & 0.33 & 0 & 0 & 0 & 0.00 & 0.00 & 0.00 & 0.00 \\
\hline Laguna Verde, Valparaíso & -33.115 & -71.666 & Valparaíso & 360 & 2006 & 0.83 & 0.00 & 0.56 & 0.00 & 0.00 & 0.00 & 0.00 & 0.00 & 0.00 & 0.56 & 0.00 & 0 & 0 & 0 & 0.00 & 0.00 & 0.00 & 0.00 \\
\hline Las Docas, Valparaíso & -33.138 & -71.703 & Valparaíso & 495 & 2018 & 3.23 & 0.00 & 0.40 & 0.00 & 0.00 & 0.00 & 1.41 & 1.01 & 0.00 & 0.00 & 0.00 & 0 & 0 & 0 & 0.00 & 0.00 & 0.00 & 0.00 \\
\hline Alto el Manzano, TilTil & -33.165 & -70.790 & Metropolitan & 300 & 2010 & 0.00 & 0.00 & 0.00 & 0.00 & 0.00 & 0.00 & 0.00 & 0.00 & 2.33 & 0.00 & 0.00 & 0 & 0 & 0 & 0.00 & 0.00 & 0.00 & 0.00 \\
\hline $\begin{array}{l}\text { San Antonio de Naltahua, Isla de } \\
\text { Maipo }\end{array}$ & -33.436 & -71.021 & Metropolitan & 300 & 2004 & 0.00 & 0.00 & 0.67 & 0.00 & 0.00 & 0.00 & 0.00 & 0.00 & 0.00 & 0.00 & 0.67 & 0 & 0 & 0 & 0.00 & 0.00 & 0.00 & 0.00 \\
\hline La Reina, La Reina & -33.456 & -70.517 & Metropolitan & 150 & 2003 & 0.00 & 0.00 & 0.67 & 0.00 & 0.00 & 0.00 & 0.00 & 0.00 & 0.00 & 0.00 & 2.00 & 0 & 0 & 0 & 0.00 & 0.00 & 0.00 & 0.00 \\
\hline Lo Espejo, Lo Espejo & -33.543 & -70.696 & Metro & 600 & 2013 & 0.00 & 0.00 & 0.50 & 0.00 & 0.00 & 0.00 & 0.00 & 0.00 & 0.33 & 0.17 & 0.00 & 0 & 0 & 0 & 0.00 & 0.00 & 0.00 & 0.00 \\
\hline El Canelo, San Jo & -33.556 & -70.454 & Metr & 255 & 2004 & 0.00 & 0.00 & 0.00 & 0.00 & 0.00 & 0.00 & 0.39 & 0.39 & 0.00 & 0.39 & 0.78 & 0 & 0 & 0 & 0.00 & 0.00 & 0.00 & 0.00 \\
\hline La Florida Alto & -33.564 & -70.532 & Metr & 270 & 2005 & 0.37 & 0.00 & 3.33 & 0.00 & 0.00 & 0.00 & 0.00 & 0.00 & 0.00 & 0.00 & 0.00 & 0 & 0 & 0 & 0.00 & 0.00 & 0.00 & 0.00 \\
\hline Mallarauco, Melipilla & -33.569 & -71.180 & Metropolitan & 300 & 2012 & 0.00 & 0.00 & 1.67 & 0.00 & 0.00 & 0.00 & 0.33 & 0.00 & 2.00 & 0.00 & 0.00 & 0 & 0 & 0 & 0.00 & 0.00 & 0.00 & 0.00 \\
\hline San Antonio, San Antonio & -33.643 & -71.563 & Valparaíso & 225 & 2001 & 0.00 & 0.00 & 0.00 & 0.00 & 0.00 & 0.00 & 0.44 & 0.00 & 1.33 & 0.00 & 0.89 & 0 & 0 & 0 & 0.00 & 0.00 & 0.00 & 0.00 \\
\hline Pomaire, Melipilla & -33.650 & -71.179 & Metropolitan & 450 & 2006 & 0.00 & 0.00 & 0.89 & 0.00 & 0.00 & 0.00 & 0.00 & 0.00 & 0.00 & 0.22 & 0.22 & 0 & 0 & 0 & 0.00 & 0.00 & 0.00 & 0.00 \\
\hline Constructora Inca, Melipilla & -33.673 & -71.180 & etropolitan & 312 & 2013 & 0.00 & 0.00 & 2.56 & 0.00 & 0.00 & 0.00 & 0.00 & 0.00 & 0.32 & 0.00 & 0.00 & 0 & 0 & 0 & 0.00 & 0.00 & 0.00 & 0.00 \\
\hline Condominio Puerta del Sol, Talagante & -33.677 & -70.845 & itan & 300 & 2006 & 0.00 & 0.00 & 1.33 & 0.00 & 0.00 & 0.00 & 0.33 & 0.00 & 0.00 & 0.00 & 0.00 & 0 & 0 & 0 & 0.00 & 0.00 & 0.00 & 0.00 \\
\hline Talagante, Talagante & -33.681 & -70.877 & Metro & 24 & 2001 & 0.00 & 0.00 & 6.67 & 0.00 & 0.00 & 0.00 & 0.00 & 0.00 & 0.42 & 2.08 & 0.00 & 0 & 0 & 0 & 0.00 & 0.00 & 0.00 & 0.00 \\
\hline & 2072 & -71 & & & 2003 & 0.00 & 0.00 & 3.67 & 0.00 & 0.00 & 0.00 & 0.33 & 0.00 & 0.00 & 0.67 & 0.00 & 0 & 0 & 0 & 0.00 & 0.00 & 0.00 & 0.00 \\
\hline Fundo La Ventol & -33.743 & -71 & & 30 & 2002 & 4.00 & 0.00 & 6.67 & 0.00 & 0.00 & 0.00 & 0.00 & 0.00 & 0.00 & 0.67 & 0.00 & 0 & 0 & 0 & 0.00 & 0.00 & 0.00 & 0.00 \\
\hline El Ingenio, Se & -33.786 & -70.2 & Metrs & 30 & 2002 & 0.00 & 0.00 & 0.33 & 0.00 & 0.00 & 0.00 & 0.00 & 0.00 & 0.00 & 0.33 & 0.00 & 0 & 0 & 0 & 0.00 & 0.00 & 0.00 & 0.00 \\
\hline Hijuel & -33.813 & -71.147 & Valp & 2 & 2001 & 0.00 & 0.00 & 0.95 & 0.00 & 0.00 & 0.00 & 0.00 & 0.00 & 0.95 & 0.48 & 0.00 & 0 & 0 & 0 & 0.00 & 0.00 & 0.00 & 0.00 \\
\hline & - & -70 & & & & 0.00 & 0.00 & 1.00 & 0.00 & 0.00 & 0.00 & 0.00 & 0.00 & 0.33 & 0.33 & 1.00 & 0 & 0 & 0 & 0.00 & 0.00 & 0.00 & 0.00 \\
\hline Ucúqu & -33.998 & -71.650 & & 4 & 2013 & 0.00 & 0.00 & 3.11 & 0.00 & 0.00 & 0.00 & 1.33 & 1.33 & 0.00 & 0.00 & 1.11 & 0 & 0 & 1 & 0.00 & 0.00 & 0.32 & 0.15 \\
\hline Quilamuta-Las Cabras, Las Cabras & -34.070 & -71.300 & & 300 & 2002 & 0.33 & 0.00 & 1.00 & 0.00 & 0.00 & 0.00 & 2.67 & 0.00 & 0.00 & 0.67 & 0.00 & 0 & 0 & 0 & 0.00 & 0.00 & 0.00 & 0.00 \\
\hline Coya, Machalí & -34.190 & -70.534 & O'Higgins & 145 & 2002 & 0.00 & 0.00 & 0.69 & 0.00 & 0.00 & 0.00 & 0.69 & 1.38 & 0.00 & 3.45 & 0.00 & 1 & 0 & 0 & 1.45 & 0.00 & 0.00 & 0.16 \\
\hline $\begin{array}{c}\text { San Vicente de Tagua Tagua, San } \\
\text { Vicente de Tagua Tagua }\end{array}$ & -34.433 & & O'Higgins & 714 & 2011 & 0.00 & 0.00 & 0.28 & 0.00 & 0.00 & 0.00 & 0.00 & 0.00 & 0.42 & 0.00 & 0.14 & 0 & 0 & 0 & 0.00 & 0.00 & 0.00 & 0.00 \\
\hline Los Maitenes, Lolol & -34.671 & -71.554 & & 652 & 2017 & 0.00 & 0.00 & 0.46 & 0.00 & 0.00 & 0.00 & 0.31 & 0.00 & 0.15 & 0.31 & 0.00 & 0 & 0 & 0 & 0.00 & 0.00 & 0.00 & 0.00 \\
\hline Las Peñas, & -34.766 & -70.776 & & 36 & 2002 & 0.00 & 0.00 & 0.56 & 0.00 & 0.00 & 0.00 & 0.28 & 0.00 & 0.00 & 0.00 & 0.00 & 1 & 0 & 0 & 3.60 & 0.00 & 0.00 & 1.20 \\
\hline Las $P \mathrm{e}$ & -34.767 & -70.776 & & 60 & 2018 & 0.00 & 0.00 & 1.33 & 0.00 & 0.00 & 0.00 & 0.00 & 0.33 & 0.00 & 0.50 & 1.00 & 0 & 0 & 0 & 0.00 & 0.00 & 0.00 & 0.00 \\
\hline & -34.815 & & $\mathrm{O}^{\prime} \mathrm{Hig}$ & 39 & 2012 & 0.00 & 0.00 & 2.31 & 0.00 & 0.00 & 0.00 & 0.77 & 0.00 & 0.00 & 0.00 & 0.26 & 1 & 0 & 0 & 1.30 & 0.00 & 0.00 & 0.30 \\
\hline Lipimá & -34.870 & -72.147 & & 450 & 2010 & 0.44 & 0.00 & 0.22 & 0.00 & 0.00 & 0.00 & 1.78 & 0.00 & 0.00 & 0.00 & 0.00 & 0 & 0 & 0 & 0.00 & 0.00 & 0.00 & 0.00 \\
\hline Duao, Licantén & -34.882 & -72.154 & Maule & 300 & 2003 & 1.00 & 0.00 & 8.00 & 0.00 & 0.00 & 0.00 & 12.33 & 30.00 & 0.00 & 0.67 & 0.00 & 4 & 0 & 0 & 0.32 & 0.00 & 0.00 & 0.18 \\
\hline Escuela Quilpoco, Rauco & -34.955 & -71.346 & Maule & 270 & 2018 & 0.00 & 0.00 & 0.00 & 0.00 & 0.00 & 0.00 & 0.37 & 0.00 & 0.37 & 1.11 & 0.00 & 1 & 0 & 0 & 2.70 & 0.00 & 0.00 & 0.54 \\
\hline El Pumaitén, Romeral & -34.967 & -71.125 & Maule & 300 & 2002 & 0.67 & 0.00 & 3.00 & 0.00 & 0.00 & 0.00 & 0.33 & 0.00 & 0.00 & 0.00 & 0.67 & 0 & 0 & 0 & 0.00 & 0.00 & 0.00 & 0.00 \\
\hline
\end{tabular}


Table A1. Cont.

\begin{tabular}{|c|c|c|c|c|c|c|c|c|c|c|c|c|c|c|c|c|c|c|c|c|c|c|c|}
\hline \multirow[b]{2}{*}{ Locality, County } & \multirow[b]{2}{*}{ Latitude } & \multirow[b]{2}{*}{ Longitude } & \multirow[b]{2}{*}{$\begin{array}{l}\text { Administrative } \\
\text { Region }\end{array}$} & \multirow[b]{2}{*}{ Total Traps } & \multirow[b]{2}{*}{ Year } & \multicolumn{11}{|c|}{ Relative Abundance } & \multicolumn{3}{|c|}{ Seropositives } & \multicolumn{4}{|c|}{ Relative Seropositivity } \\
\hline & & & & & & Al & Ah & Ao & As & $\mathrm{Am}$ & $\mathrm{Lm}$ & Ol & Pd & $\mathrm{Mm}$ & $\mathbf{R n}$ & $\mathrm{Rr}$ & Ol & $\mathrm{Ah}$ & Ao & Ol & Ah & Ao & Tota \\
\hline Hualañé, Hualañé 2010 & -34.971 & -71.833 & Maule & 450 & 2010 & 0.00 & 0.00 & 0.22 & 0.00 & 0.00 & 0.00 & 1.33 & 0.00 & 0.00 & 0.00 & 0.00 & 0 & 0 & 0 & 0.00 & 0.00 & 0.00 & 0.00 \\
\hline El Trapiche, Curicó & -34.983 & -71.317 & Maule & 600 & 2004 & 0.00 & 0.00 & 3.00 & 0.00 & 0.00 & 0.00 & 1.00 & 0.00 & 0.33 & 0.17 & 0.50 & 1 & 0 & 0 & 1.00 & 0.00 & 0.00 & 0.20 \\
\hline Hualañé, Hualañé 2012 & -34.990 & -71.847 & Maule & 360 & 2012 & 0.00 & 0.00 & 3.06 & 0.00 & 0.00 & 0.00 & 0.56 & 0.00 & 0.00 & 0.00 & 0.00 & 0 & 0 & 0 & 0.00 & 0.00 & 0.00 & 0.00 \\
\hline Palquibudi, Rauco & -35.030 & -71.549 & Maule & 270 & 2002 & 0.00 & 0.00 & 0.74 & 0.00 & 0.00 & 0.00 & 0.37 & 0.00 & 0.00 & 0.37 & 0.00 & 0 & 0 & 0 & 0.00 & 0.00 & 0.00 & 0.00 \\
\hline Los Queñes, Romeral & -35.125 & -70.773 & Maule & 360 & 2012 & 0.00 & 0.00 & 0.28 & 0.00 & 0.00 & 0.00 & 1.11 & 0.00 & 0.00 & 0.28 & 1.39 & 4 & 0 & 1 & 3.60 & 0.00 & 3.60 & 1.64 \\
\hline Las Lomas, San Clemente & -35.484 & -71.227 & Maule & 300 & 2002 & 0.00 & 0.00 & 0.67 & 0.00 & 0.00 & 0.00 & 0.00 & 0.00 & 0.00 & 0.00 & 0.67 & 0 & 0 & 0 & 0.00 & 0.00 & 0.00 & 0.00 \\
\hline Canal Melado, Longaví & -36.017 & -71.501 & Maule & 375 & 2002 & 0.00 & 0.27 & 1.87 & 0.00 & 0.00 & 0.00 & 0.80 & 0.00 & 0.00 & 0.00 & 0.00 & 1 & 0 & 0 & 1.25 & 0.00 & 0.00 & 0.34 \\
\hline Retupel, Cauquenes & -36.018 & -72.462 & Maule & 300 & 2003 & 0.00 & 0.00 & 2.33 & 0.00 & 0.00 & 0.00 & 1.67 & 0.00 & 0.00 & 0.00 & 0.00 & 1 & 0 & 0 & 0.60 & 0.00 & 0.00 & 0.25 \\
\hline Bullileo, Parral & -36.289 & -71.413 & Maule & 240 & 2001 & 0.00 & 0.42 & 0.00 & 0.00 & 0.00 & 0.00 & 1.25 & 0.00 & 0.00 & 0.42 & 1.25 & 0 & 0 & 0 & 0.00 & 0.00 & 0.00 & 0.00 \\
\hline San Miguel de Ablemo, San Carlos & -36.452 & -71.990 & Ñuble & 324 & 2003 & 0.00 & 0.00 & 7.10 & 0.00 & 0.00 & 0.00 & 3.09 & 0.00 & 0.00 & 0.93 & 1.54 & 0 & 0 & 0 & 0.00 & 0.00 & 0.00 & 0.00 \\
\hline Tres Esquinas, Coihueco & -36.556 & -71.766 & Biobío & 675 & 2013 & 0.00 & 0.00 & 0.15 & 0.00 & 0.00 & 0.00 & 0.00 & 0.00 & 0.00 & 0.00 & 0.00 & 0 & 0 & 0 & 0.00 & 0.00 & 0.00 & 0.00 \\
\hline Agua Tendida, Tomé & -36.641 & -72.796 & Biobío & 300 & 2004 & 0.00 & 3.67 & 5.67 & 0.00 & 0.00 & 0.00 & 3.33 & 0.67 & 0.00 & 0.33 & 0.33 & 2 & 1 & 0 & 0.60 & 0.27 & 0.00 & 0.21 \\
\hline Chillán-Pinto, Chillán & -36.651 & -71.999 & Ñuble & 300 & 2003 & 0.00 & 1.33 & 7.67 & 0.00 & 0.00 & 0.00 & 3.00 & 0.00 & 0.33 & 0.33 & 0.67 & 1 & 0 & 0 & 0.33 & 0.00 & 0.00 & 0.08 \\
\hline Lloicura, Tomé & -36.689 & -72.762 & Biobío & 306 & 2003 & 0.00 & 1.63 & 0.00 & 0.00 & 0.00 & 0.00 & 0.00 & 0.00 & 0.00 & 0.00 & 0.33 & 0 & 0 & 0 & 0.00 & 0.00 & 0.00 & 0.00 \\
\hline Peñablanca, Quillón & -36.713 & -72.572 & Ñuble & 288 & 2001 & 0.00 & 0.35 & 1.39 & 0.00 & 0.00 & 0.00 & 2.08 & 0.00 & 0.00 & 1.04 & 0.69 & 0 & 0 & 0 & 0.00 & 0.00 & 0.00 & 0.00 \\
\hline Vilumanque, Concepción & -36.784 & -73.012 & Biobío & 218 & 2003 & 0.00 & 8.72 & 8.26 & 0.00 & 0.00 & 0.00 & 11.93 & 30.00 & 0.00 & 0.00 & 0.46 & 0 & 0 & 0 & 0.00 & 0.00 & 0.00 & 0.00 \\
\hline Chaimávida, Concepción & -36.799 & -72.952 & Biobío & 450 & 2009 & 0.00 & 0.44 & 1.11 & 0.00 & 0.00 & 0.00 & 2.89 & 0.00 & 0.00 & 0.00 & 0.00 & 0 & 0 & 0 & 0.00 & 0.00 & 0.00 & 0.00 \\
\hline Forestal Millalemu, El Carmen & -36.931 & -71.744 & Ñuble & 450 & 2005 & 0.00 & 0.67 & 0.89 & 0.00 & 0.00 & 0.00 & 4.22 & 0.00 & 0.00 & 0.00 & 0.22 & 0 & 0 & 0 & 0.00 & 0.00 & 0.00 & 0.00 \\
\hline Talcamávida, Hualqui & -37.142 & -72.908 & Biobío & 450 & 2005 & 0.00 & 1.56 & 0.67 & 0.00 & 0.00 & 0.00 & 1.56 & 0.00 & 0.44 & 0.00 & 0.22 & 0 & 0 & 0 & 0.00 & 0.00 & 0.00 & 0.00 \\
\hline Forestal Millalemu, Tucapel & -37.241 & -71.794 & Biobío & 300 & 2002 & 0.00 & 1.33 & 7.00 & 0.00 & 0.00 & 0.00 & 3.00 & 0.00 & 0.00 & 0.00 & 0.33 & 2 & 0 & 0 & 0.67 & 0.00 & 0.00 & 0.17 \\
\hline Santa Juana, Santa Juana & -37.342 & -72.932 & Biobío & 450 & 2009 & 0.00 & 0.67 & 0.00 & 0.00 & 0.00 & 0.00 & 2.22 & 0.00 & 0.00 & 0.44 & 0.00 & 0 & 0 & 0 & 0.00 & 0.00 & 0.00 & 0.00 \\
\hline Los Ángeles, Los Ángeles & -37.463 & -72.303 & Biobío & 312 & 2000 & 0.00 & 0.00 & 1.28 & 0.00 & 0.00 & 0.00 & 0.00 & 0.00 & 0.00 & 0.64 & 0.00 & 0 & 0 & 0 & 0.00 & 0.00 & 0.00 & 0.00 \\
\hline Cañicura, Quilleco & -37.541 & -72.688 & Biobío & 600 & 2018 & 0.00 & 0.17 & 3.33 & 0.00 & 0.00 & 0.00 & 2.83 & 0.00 & 0.00 & 0.50 & 0.50 & 3 & 0 & 0 & 1.06 & 0.00 & 0.00 & 0.41 \\
\hline Hacienda San Lorenzo, Quilleco & -37.546 & -71.463 & Biobío & 450 & 2005 & 0.00 & 2.44 & 2.67 & 0.00 & 0.00 & 0.67 & 1.33 & 0.00 & 0.00 & 0.00 & 0.00 & 0 & 0 & 0 & 0.00 & 0.00 & 0.00 & 0.00 \\
\hline Alto las Viñas, Los Ángeles & -37.559 & -72.544 & Biobío & 300 & 2004 & 0.00 & 0.00 & 8.67 & 0.00 & 0.00 & 0.00 & 2.67 & 0.00 & 0.33 & 0.00 & 0.67 & 0 & 0 & 0 & 0.00 & 0.00 & 0.00 & 0.00 \\
\hline Antihuala, Los Álamos & -37.706 & -73.419 & Biobío & 300 & 2006 & 0.00 & 1.00 & 0.33 & 0.00 & 0.00 & 0.00 & 1.67 & 0.00 & 0.00 & 0.33 & 2.67 & 0 & 0 & 0 & 0.00 & 0.00 & 0.00 & 0.00 \\
\hline La Curva, Cañete & -37.796 & -73.308 & Araucanía & 600 & 2013 & 0.00 & 0.17 & 1.00 & 0.00 & 0.00 & 0.00 & 0.33 & 0.00 & 0.00 & 1.33 & 0.00 & 0 & 0 & 0 & 0.00 & 0.00 & 0.00 & 0.00 \\
\hline Llacolén, Contulmo & -37.916 & -73.273 & Biobío & 675 & 2013 & 0.00 & 0.59 & 1.04 & 0.00 & 0.00 & 0.00 & 3.26 & 0.00 & 0.00 & 0.00 & 0.00 & 0 & 0 & 0 & 0.00 & 0.00 & 0.00 & 0.00 \\
\hline Llanquén, Lonquimay & -38.150 & -71.300 & Araucanía & 600 & 2014 & 0.00 & 2.00 & 0.00 & 0.00 & 0.00 & 1.67 & 1.33 & 0.00 & 0.00 & 0.00 & 0.00 & 3 & 0 & 0 & 2.25 & 0.00 & 0.00 & 0.60 \\
\hline Tirúa, Tirúa & -38.272 & -73.513 & Biobío & 270 & 2006 & 0.00 & 0.00 & 1.11 & 0.00 & 0.00 & 0.00 & 1.11 & 0.00 & 0.00 & 0.00 & 0.00 & 0 & 0 & 0 & 0.00 & 0.00 & 0.00 & 0.00 \\
\hline Lautaro, Lautaro & -38.527 & -72.429 & Araucanía & 300 & 2002 & 0.00 & 0.00 & 2.00 & 0.00 & 0.00 & 0.00 & 0.33 & 0.00 & 0.67 & 0.00 & 0.00 & 0 & 0 & 0 & 0.00 & 0.00 & 0.00 & 0.00 \\
\hline Fundo La Aguada, Gorbea & -39.060 & -72.400 & Araucanía & 450 & 2005 & 0.00 & 1.56 & 0.44 & 0.00 & 0.00 & 0.00 & 0.00 & 0.00 & 0.00 & 0.22 & 0.22 & 0 & 2 & 0 & 0.00 & 1.29 & 0.00 & 0.82 \\
\hline Lago Colico, Cunco & -39.064 & -71.973 & Araucanía & 183 & 2008 & 0.00 & 2.19 & 1.09 & 0.00 & 0.00 & 0.00 & 12.57 & 70.00 & 0.00 & 0.55 & 1.09 & 1 & 0 & 0 & 0.08 & 0.00 & 0.00 & 0.06 \\
\hline Boroa Norte, Toltén & -39.286 & -73.076 & Araucanía & 310 & 2013 & 0.00 & 0.00 & 0.32 & 0.00 & 0.00 & 0.00 & 6.13 & 0.00 & 0.00 & 0.32 & 3.55 & 2 & 0 & 0 & 0.33 & 0.00 & 0.00 & 0.19 \\
\hline Loncoche, Loncoche & -39.371 & -72.612 & Araucanía & 240 & 2003 & 0.00 & 2.08 & 1.67 & 0.00 & 0.00 & 0.00 & 2.50 & 0.00 & 0.00 & 0.00 & 0.42 & 0 & 0 & 0 & 0.00 & 0.00 & 0.00 & 0.00 \\
\hline Llancahue Alto, Panguipulli & -39.527 & -71.813 & Los Ríos & 600 & 2014 & 0.00 & 3.83 & 0.00 & 0.00 & 0.00 & 0.17 & 0.00 & 0.00 & 0.00 & 0.00 & 0.00 & 0 & 3 & 0 & 0.00 & 0.78 & 0.00 & 0.75 \\
\hline Fundo Miraflores, Lanco & -39.543 & -72.630 & Los Ríos & 675 & 2013 & 0.00 & 0.74 & 1.04 & 0.00 & 0.00 & 0.00 & 8.74 & 0.00 & 0.00 & 0.00 & 0.00 & 6 & 1 & 0 & 0.69 & 1.35 & 0.00 & 0.67 \\
\hline Ñancul, Panguipulli & -39.729 & -72.402 & Los Ríos & 120 & 2001 & 0.00 & 0.00 & 3.33 & 0.00 & 0.00 & 0.00 & 17.50 & 00.00 & 0.00 & 0.83 & 1.67 & 0 & 0 & 0 & 0.00 & 0.00 & 0.00 & 0.00 \\
\hline Huellelhue-Pishuinco, Valdivia & -39.806 & -73.069 & Los Ríos & 306 & 2003 & 0.00 & 1.63 & 6.54 & 0.00 & 0.00 & 0.00 & 0.65 & 0.00 & 0.00 & 0.00 & 0.33 & 0 & 0 & 0 & 0.00 & 0.00 & 0.00 & 0.00 \\
\hline $\begin{array}{l}\text { Campamento Vientos del Sur, } \\
\text { Valdivia }\end{array}$ & -39.824 & -73.204 & Los Ríos & 300 & 2003 & 0.00 & 1.00 & 1.00 & 0.00 & 0.00 & 0.00 & 2.33 & 0.00 & 0.00 & 0.33 & 1.00 & 1 & 0 & 0 & 0.43 & 0.00 & 0.00 & 0.18 \\
\hline San Carlos, Corral & -39.862 & -73.444 & Los Ríos & 136 & 2011 & 0.00 & 0.00 & 3.68 & 0.00 & 0.00 & 0.00 & 1.47 & 0.00 & 0.00 & 0.74 & 0.74 & 0 & 0 & 0 & 0.00 & 0.00 & 0.00 & 0.00 \\
\hline
\end{tabular}


Table A1. Cont.

\begin{tabular}{|c|c|c|c|c|c|c|c|c|c|c|c|c|c|c|c|c|c|c|c|c|c|c|c|}
\hline \multirow[b]{2}{*}{ Locality, County } & \multirow[b]{2}{*}{ Latitude } & \multirow[b]{2}{*}{ Longitude } & \multirow[b]{2}{*}{$\begin{array}{l}\text { Administrative } \\
\text { Region }\end{array}$} & \multirow[b]{2}{*}{ Total Traps } & \multirow[b]{2}{*}{ Year } & \multicolumn{11}{|c|}{ Relative Abundance } & \multicolumn{3}{|c|}{ Seropositives } & \multicolumn{4}{|c|}{ Relative Seropositivity } \\
\hline & & & & & & Al & Ah & Ao & As & $\mathrm{Am}$ & $\mathrm{Lm}$ & Ol & Pd & $\mathrm{Mm}$ & $\mathbf{R n}$ & $\mathrm{Rr}$ & $\mathrm{Ol}$ & Ah & Ao & $\mathrm{Ol}$ & Ah & Ao & Tota \\
\hline Playa San Julián, Corral & -39.905 & -73.379 & Los Ríos & 330 & 2011 & 0.00 & 7.27 & 1.52 & 0.00 & 0.00 & 0.00 & 0.61 & 0.00 & 0.00 & 0.61 & 0.30 & 0 & 1 & 0 & 0.00 & 0.14 & 0.00 & 0.10 \\
\hline Fundo Futangue, Lago Ranco & -40.365 & -72.315 & Los Ríos & 273 & 2002 & 0.00 & 3.30 & 2.20 & 0.73 & 0.00 & 0.00 & 3.30 & 0.00 & 0.00 & 0.00 & 0.00 & 0 & 0 & 0 & 0.00 & 0.00 & 0.00 & 0.00 \\
\hline Las Quemas, Osorno & -40.630 & -73.115 & Los Lagos & 340 & 2017 & 0.00 & 0.88 & 3.53 & 0.00 & 0.29 & 0.59 & 0.00 & 0.00 & 0.00 & 0.59 & 0.00 & 0 & 1 & 2 & 0.00 & 1.13 & 0.57 & 0.51 \\
\hline Nilque, Puyehue & -40.725 & -72.434 & Los Lagos & 270 & 2004 & 0.00 & 2.96 & 1.85 & 0.00 & 0.00 & 0.00 & 5.56 & 0.00 & 0.00 & 0.37 & 0.00 & 0 & 1 & 0 & 0.00 & 0.34 & 0.00 & 0.09 \\
\hline El Encanto, Puyehue & -40.760 & -72.444 & Los Lagos & 540 & 2017 & 0.00 & 2.04 & 1.67 & 0.00 & 1.11 & 0.00 & 4.07 & 0.00 & 0.00 & 0.37 & 0.37 & 0 & 0 & 1 & 0.00 & 0.00 & 0.60 & 0.10 \\
\hline Rupanquito, Osorno & -40.772 & -72.783 & Los Lagos & & 2013 & 0.00 & 0.97 & 3.23 & 0.00 & 0.00 & 0.00 & 8.39 & 0.00 & 0.32 & 0.32 & 0.65 & 2 & 0 & 0 & 0.24 & 0.00 & 0.00 & 0.14 \\
\hline El Cabrito, Puerto Octay & -40.909 & -72.410 & Los Lagos & 330 & 2011 & 0.00 & 1.82 & 2.42 & 0.00 & 0.00 & 0.00 & 6.06 & 0.00 & 0.00 & 0.30 & 0.00 & 1 & 1 & 0 & 0.17 & 0.55 & 0.00 & 0.19 \\
\hline Peulla, Puerto Varas & -41.086 & -72.018 & & & 2006 & 0.00 & 2.22 & 0.83 & 0.00 & 0.00 & 0.00 & 0.56 & 0.00 & 0.00 & 0.00 & 0.83 & 0 & 0 & 0 & 0.00 & 0.00 & 0.00 & 0.00 \\
\hline Fundo Pichi-Juan, Puerto Varas & -41.243 & -72.722 & Los Lagos & 600 & 2013 & 0.00 & 0.17 & 1.83 & 0.00 & 0.17 & 0.17 & 5.33 & 0.00 & 0.00 & 0.00 & 0.00 & 0 & 0 & 0 & 0.00 & 0.00 & 0.00 & 0.00 \\
\hline Las Quemas, Puerto Montt & -41.416 & -73191.000 & & 771 & 2002 & 0.00 & 0.13 & 1.43 & 0.00 & 0.00 & 0.13 & 0.39 & 0.00 & 0.00 & 0.00 & 0.13 & 0 & 0 & 0 & 0.00 & 0.00 & 0.00 & 0.00 \\
\hline Caleta Rollizo, Cochamó & -41.430 & -72.308 & Los Lagos & 402 & 2011 & 0.00 & 0.25 & 3.98 & 0.00 & 0.00 & 0.00 & 1.99 & 0.00 & 0.00 & 0.00 & 0.00 & 0 & 1 & 0 & 0.00 & 4.02 & 0.00 & 0.16 \\
\hline Paso El León, Cochamó & -41.532 & -71.831 & Los Lagos & 300 & 2006 & 0.00 & 4.00 & 1.00 & 0.00 & 0.00 & 0.00 & 12.33 & 30.00 & 0.00 & 0.00 & 0.00 & 1 & 0 & 0 & 0.08 & 0.00 & 0.00 & 0.06 \\
\hline Parque Nacional Chiloé, Chonchi & -42.622 & -74.106 & Los Lagos & 675 & 2013 & 0.00 & 0.00 & 4.30 & 1.04 & 0.00 & 0.00 & 1.04 & 0.00 & 0.00 & 0.15 & 0.00 & 0 & 0 & 0 & 0.00 & 0.00 & 0.00 & 0.00 \\
\hline Cerro Negro, Coyhaique & -45.583 & -71.940 & Aysén & 360 & 2004 & 0.00 & 0.56 & 0.28 & 0.00 & 0.00 & 0.00 & 0.56 & 0.00 & 0.00 & 0.00 & 0.00 & 0 & 0 & 0 & 0.00 & 0.00 & 0.00 & 0.00 \\
\hline
\end{tabular}

$\mathrm{Al}=$ Abrothrix longipilis, $\mathrm{Ah}=$ Abrothrix hirta, Ao $=$ Abrothrix olivacea, As $=$ Abrothrix sanborni, Am = Abrothrix manni, Lm $=$ Loxodontomys micropus, Ol $=$ Oligoryzomys longicaudatus, $\mathrm{Pd}=$ Phyllotis darwini, $\mathrm{Mm}=$ Mus musculus, $\mathrm{Rn}=$ Rattus norvegicus, $\mathrm{Rr}=$ Rattus rattus 


\section{References}

1. Morse, S.S. Factors in the emergence of infectious diseases. Emerg. Infect. Dis. 1995, 1, 7-15. [CrossRef] [PubMed]

2. Cutler, S.J.; Fooks, A.R.; van der Poel, W.H.M. Public health threat of new, reemerging, and neglected zoonoses in the industrialized world. Emerg. Infect. Dis. 2010, 16, 1-7. [CrossRef] [PubMed]

3. Jonsson, C.B.; Schmaljohn, C.S. Replication of hantaviruses. Curr. Top. Microbiol. Immunol. 2001, 256, 15-32. [PubMed]

4. Schmaljohn, C.; Hjelle, B. Hantaviruses: A global disease problem. Emerg. Infect. Dis. 1997, 3, 95-104. [CrossRef] [PubMed]

5. Hjelle, B.; Torres-Pérez, F. Hantaviruses in the Americas and their role as emerging pathogens. Viruses 2010, 2, 2559-2586. [CrossRef] [PubMed]

6. Jonsson, C.B.; Figueiredo, L.T.M.; Vapalahti, O. A global perspective on hantavirus ecology, epidemiology, and disease. Clin. Microbiol. Rev. 2010, 23, 412-441. [CrossRef]

7. Nichol, S.T.; Spiropoulou, C.F.; Morzunov, S.; Rollin, P.E.; Ksiazek, T.G.; Feldmann, H.; Sánchez, A.; Childs, J.; Zaki, S.; Peters, C.J. Genetic identification of a hantavirus associated with an outbreak of acute respiratory illness. Science 1993, 262, 914-917. [CrossRef]

8. Childs, J.E.; Ksiazek, T.G.; Spiropoulou, C.F.; Krebs, J.W.; Morzunov, S.; Maupin, G.O.; Gage, K.L.; Rollin, P.E.; Sarisky, J.; Enscore, R.E. Serologic and genetic identification of Peromyscus maniculatus as the primary rodent reservoir for a new hantavirus in the southwestern United States. J. Infect. Dis. 1994, 169, 1271-1280. [CrossRef]

9. Arai, S.; Ohdachi, S.D.; Asakawa, M.; Kang, H.J.; Mocz, G.; Arikawa, J.; Okabe, N.; Yanagihara, R. Molecular phylogeny of a newfound hantavirus in the Japanese shrew mole (Urotrichus talpoides). Proc. Natl. Acad. Sci. USA 2008, 105, 16296-16301. [CrossRef]

10. Klempa, B.; Fichet-Calvet, E.; Lecompte, E.; Auste, B.; Aniskin, V.; Meisel, H.; Barriere, P.; Koivogui, L.; ter Meulen, J.; Kruger, D.H. Novel hantavirus sequences in Shrew, Guinea. Emerg. Infect. Dis. 2007, 13, 520-522. [CrossRef]

11. Kang, H.J.; Kosoy, M.Y.; Shrestha, S.K.; Shrestha, M.P.; Pavlin, J.A.; Gibbons, R.V.; Yanagihara, R. Genetic diversity of Thottapalayam virus, a hantavirus harbored by the Asian house shrew (Suncus murinus) in Nepal. Am. J. Trop. Med. Hyg. 2011, 85, 540-545. [CrossRef] [PubMed]

12. Arai, S.; Bennett, S.N.; Sumibcay, L.; Cook, J.A.; Song, J.-W.W.; Hope, A.; Parmenter, C.; Nerurkar, V.R.; Yates, T.L.; Yanagihara, R. Phylogenetically distinct hantaviruses in the masked shrew (Sorex cinereus) and dusky shrew (Sorex monticolus) in the United States. Am. J. Trop. Med. Hyg. 2008, 78, 348-351. [CrossRef] [PubMed]

13. Guo, W.-P.; Lin, X.-D.; Wang, W.; Tian, J.-H.; Cong, M.-L.; Zhang, H.-L.; Wang, M.-R.; Zhou, R.-H.; Wang, J.-B.; Li, M.-H.; et al. Phylogeny and origins of hantaviruses harbored by bats, insectivores, and rodents. PLoS Pathogens 2013, 9, e1003159. [CrossRef] [PubMed]

14. MacNeil, A.; Ksiazek, T.G.; Rollin, P.E. Hantavirus pulmonary syndrome, United States, 1993-2009. Emerg. Infect. Dis. 2011, 17, 1195-1201. [CrossRef] [PubMed]

15. Martinez, V.P.; Bellomo, C.M.; Cacace, M.L.; Suárez, P.; Bogni, L.; Padula, P.J. Hantavirus pulmonary syndrome in Argentina, 1995-2008. Emerg. Infect. Dis. 2010, 16, 1853-1860. [CrossRef] [PubMed]

16. Ferrés, M.; Vial, P.; Marco, C.; Yañez, L.; Godoy, P.; Castillo, C.; Hjelle, B.; Delgado, I.; Lee, S.J.; Mertz, G.J. Prospective evaluation of household contacts of persons with hantavirus cardiopulmonary syndrome in Chile. J. Infect. Dis. 2007, 195, 1563-1571. [CrossRef] [PubMed]

17. Centers for Disease Control and Prevention. Annual, US. Hantavirus Disease and HPS Case Fatality; Centers for Disease Control and Prevention: Atlanta, GA, USA, 1993-2018.

18. Levis, S.; Morzunov, S.P.; Rowe, J.E.; Enria, D.; Pini, N.; Calderón, G.; Sabattini, M.; St Jeor, S.C. Genetic diversity and epidemiology of hantaviruses in Argentina. J. Infect. Dis. 1998, 177, 529-538. [CrossRef]

19. Medina, R.A.; Torres-Pérez, F.; Galeno, H.; Navarrete, M.; Vial, P.A.; Palma, R.E.; Ferrés, M.; Cook, J.A.; Hjelle, B. Ecology, genetic diversity, and phylogeographic structure of Andes virus in humans and rodents in Chile. J. Virol. 2009, 83, 2446-2459. [CrossRef] 
20. Torres-Pérez, F.; Navarrete-Droguett, J.; Aldunate, R.; Yates, T.L.; Mertz, G.J.; Vial, P.A.; Ferrés, M.; Marquet, P.A.; Palma, R.E. Peridomestic small mammals associated with confirmed cases of human hantavirus disease on southcentral Chile. Am. J. Trop. Med. Hyg. 2004, 70, 305-309. [CrossRef]

21. Padula, P.; Figueroa, R.; Navarrete, M.; Pizarro, E.; Cadiz, R.; Bellomo, C.; Jofre, C.; Zaror, L.; Rodriguez, E.; Murúa, R. Transmission study of Andes hantavirus infection in wild sigmodontine rodents. J. Virol. 2004, 78, 11972-11979. [CrossRef]

22. Martinez, V.P.; Bellomo, C.; San Juan, J.; Pinna, D.; Forlenza, R.; Elder, M.; Padula, P.J. Person-to-person transmission of Andes virus. Emerg. Infect. Dis. 2005, 11, 1848-1853. [CrossRef] [PubMed]

23. Lázaro, M.E.; Cantoni, G.E.; Calanni, L.M.; Resa, A.J.; Herrero, E.R.; Iacono, M.A.; Enria, D.A.; Cappa, S.M.G. Clusters of hantavirus infection, southern Argentina. Emerg. Infect. Dis. 2007, 13, 104-110. [CrossRef] [PubMed]

24. Martínez-Valdebenito, C.; Calvo, M.; Vial, C.; Mansilla, R.; Marco, C.; Palma, R.E.; Vial, P.A.; Valdivieso, F.; Mertz, G.; Ferrés, M. Person-to-person household and nosocomial transmission of Andes hantavirus, Southern Chile, 2011. Emerg. Infect. Dis. 2014, 20, 1637-1644. [CrossRef]

25. Padula, P.J.; Edelstein, A.; Miguel, S.D.L.; López, N.M.; Rossi, C.M.; Rabinovich, R.D. Hantavirus pulmonary syndrome outbreak in Argentina: Molecular evidence for person-to-person transmission of Andes virus. Virology 1998, 241, 323-330. [CrossRef] [PubMed]

26. Piudo, L.; Monteverde, M.J.; Walker, R.S.; Douglass, R.J. Rodent community structure and Andes virus infection in Sylvan and Peridomestic habitats in Northwestern Patagonia, Argentina. Vector Borne Zoonotic Dis. 2011, 11, 315-324. [CrossRef] [PubMed]

27. Davis, P.L.; Holmes, E.C.; Larrous, F.; van der Poel, W.H.; Tjornehoj, K.; Alonso, W.J.; Bourhy, H. Phylogeography, population dynamics, and molecular evolution of European bat lyssaviruses. J. Virol. 2005, 79, 10487-10497. [CrossRef]

28. Vadell, M.V.; Bellomo, C.; San Martín, A.; Padula, P.; Gómez Villafañe, I. Hantavirus ecology in rodent populations in three protected areas of Argentina. Trop. Med. Int. Heal. 2011, 16, 1342-1352. [CrossRef] [PubMed]

29. Toro, J.; Vega, J.D.; Khan, A.S.; Mills, J.N.; Padula, P.; Terry, W.; Yadon, Z.; Valderrama, R.; Ellis, B.A.; Pavletic, C.; et al. An outbreak of hantavirus pulmonary syndrome, Chile, 1997. Emerg. Infect. Dis. 1998, 4, 687-694. [CrossRef]

30. Ortiz, J.C.; Venegas, W.; Sandoval, J.A.; Chandía, P.; Torres-Pérez, F. Hantavirus in rodents of the VIII Region of Chile. Rev. Chile Hist. Nat. 2004, 77, 251-256.

31. Mills, J.N.; Johnson, J.M.; Ksiazek, T.G.; Ellis, B.A.; Rollin, P.E.; Yates, T.L.; Minn, M.O.; Johnson, M.R.; Campbell, M.L.; Miyashiro, J.; et al. A survey of hantavirus antibody in small-mammal populations in selected United States National Parks. Am. J. Trop. Med. Hyg. 1998, 58, 525-532. [CrossRef]

32. Sikes, R.S.; Gannon, W.L. Guidelines of the American Society of Mammalogists for the use of wild mammals in research. J. Mammal. 2011, 92, 235-253. [CrossRef]

33. Teta, P.; Pardiñas, U.F.J. Variación morfológica cualitativa y cuantitativa en Abrothrix longipilis (Cricetidae, Sigmodontinae). Mastozoología Neotropical 2014, 21, 291-309.

34. D'Elía, G.; Teta, P.; Upham, N.S.; Pardiñas, U.F.J.; Patterson, B.D. Description of a new soft-haired mouse, genus Abrothrix (Sigmodontinae), from the temperate Valdivian rainforest. J. Mammal. 2015, 96, 839-853. [CrossRef]

35. Yee, J.; Wortman, I.A.; Nofchissey, R.A.; Goade, D.; Bennett, S.G.; Webb, J.P.; Irwin, W.; Hjelle, B. Rapid and simple method for screening wild rodents for antibodies to Sin Nombre hantavirus. J. Wildl. Dis. 2003, 39, 271-277. [CrossRef] [PubMed]

36. Torres-Pérez, F.; Palma, R.E.; Hjelle, B.; Ferrés, M.; Cook, J.A. Andes virus infections in the rodent reservoir and in humans vary across contrasting landscapes in Chile. Infect. Genet. Evol. 2010, 10, 820-825. [CrossRef] [PubMed]

37. Meserve, P.L.; Le Boulengé, E. Population dynamics and ecology of small mammals in the northern Chilean semi-arid region. Fieldiana Zool. New Ser. 1987, 39, 413-431.

38. Guthmann, N.; Lozada, M.; Monjeau, J.A.; Heinemann, K.M. Population dynamics of five sigmodontine rodents of northwestern Patagonia. Acta Theriologica 1997, 42, 143-152. [CrossRef]

39. Ihaka, R.; Gentleman, R. R: A Language for data analysis and graphics. J. Comput. Graph. Stat. 1996, 5, 299-314. 
40. Kallio, E.R.; Klingström, J.; Gustafsson, E.; Manni, T.; Vaheri, A.; Henttonen, H.; Vapalahti, O.; Lundkvist, Å. Prolonged survival of Puumala hantavirus outside the host: Evidence for indirect transmission via the environment. J. Gen. Virol. 2006, 87, 2127-2134. [CrossRef]

41. Arai, S.; Kikuchi, F.; Bawm, S.; Sơn, N.; Lin, K.; Tú, V.; Aoki, K.; Tsuchiya, K.; Tanaka-Taya, K.; Morikawa, S.; et al. Molecular phylogeny of Mobatviruses (Hantaviridae) in Myanmar and Vietnam. Viruses 2019, 11, 228. [CrossRef]

42. Torres-Pérez, F.; Boric-Bargetto, D.; Palma Vásquez, R.E. Hantavirus in Chile: New rodents with potential epidemiological importance. Rev. Med. Chile 2016, 144, 818. [CrossRef] [PubMed]

43. Liphardt, S.W.; Kang, H.J.; Dizney, L.J.; Ruedas, L.A.; Cook, J.A.; Yanagihara, R. Complex history of codiversification and host switching of a newfound soricid-borne Orthohantavirus in North America. Viruses 2019, 11, 637. [CrossRef] [PubMed]

44. Palma, R.E.; Torres-Pérez, F.; Boric-Bargetto, D. The ecology and evolutionary history of Oligoryzomys longicaudatus in southern South American. In The Quintessential Naturalist: Honoring the Life and Legacy of Oliver P. Pearson; Kelt, D., Lessa, E.P., Salazar-Bravo, J., Patton, J.L., Eds.; University of California Publications in Zoology: Los Angeles, CA, USA, 2007; Volume 134, pp. 671-693.

45. Della Valle, M.G.; Edelstein, A.; Miguel, S.; Martinez, V.; Cortez, J.; Cacace, M.L.; Jurgelenas, G.; Estani, S.S.; Padula, P. Andes virus associated with hantavirus pulmonary syndrome in northern Argentina and determination of the precise site of infection. Am. J. Trop. Med. Hyg. 2002, 66, 713-720. [CrossRef] [PubMed]

46. Cautivo, K.; Schountz, T.; Acuña-Retamar, M.; Ferrés, M.; Torres-Pérez, F. Rapid enzyme-linked immunosorbent assay for the detection of hantavirus-specific antibodies in divergent small mammals. Viruses 2014, 6, 2028-2037. [CrossRef] [PubMed]

47. Kuenzi, A.J.; Douglass, R.J.; Bond, C.W.; Calisher, C.H.; Mills, J.N. Long-term dynamics of Sin Nombre viral RNA and antibody in deer mice in Montana. J. Wildl. Dis. 2005, 41, 473-481. [CrossRef] [PubMed]

48. Muñoz-Pedreros, A.; Rutherford, P.; Gil, C. Hantavirus risk maps for Conguillio National Park, Southern Chile. Rev. Chil. Hist. Nat. 2007, 80, 363-379.

49. Calderón, G.; Pini, N.; Bolpe, J.; Levis, S.; Mills, J.; Segura, E.; Guthmann, N.; Cantoni, G.; Becker, J.; Fonollat, A.; et al. Hantavirus reservoir hosts associated with peridomestic habitats in Argentina. Emerg. Infect. Dis. 1999, 5, 792-797. [CrossRef] [PubMed]

50. Rosa, E.S.T.; Mills, J.N.; Padula, P.J.; Elkhoury, M.R.; Ksiazek, T.G.; Mendes, W.S.; Santos, E.D.; Araújo, G.C.B.; Martinez, V.P.; Rosa, J.F.; et al. Newly recognized hantaviruses associated with hantavirus pulmonary syndrome in northern Brazil: Partial genetic characterization of viruses and serologic implication of likely reservoirs. Vector Borne Zoonotic Dis. 2005, 5, 11-19. [CrossRef] [PubMed]

51. Luong, L.T.; Vigliotti, B.A.; Campbell, S.; Comer, J.A.; Mills, J.N.; Hudson, P.J. Dynamics of hantavirus infection in Peromyscus leucopus of central Pennsylvania. Vector Borne Zoonotic Dis. 2011, 11, 1459-1464. [CrossRef]

52. Armién, A.G.; Armién, B.; Koster, F.; Pascale, J.M.; Avila, M.; Gonzalez, P.; de la Cruz, M.; Zaldivar, Y.; Mendoza, Y.; Gracia, F.; et al. Hantavirus infection and habitat associations among rodent populations in agroecosystems of Panama: Implications for human disease risk. Am. J. Trop. Med. Hyg. 2009, 81, 59-66. [CrossRef]

53. Salazar-Bravo, J.; Armién, B.; Suzén, G.; Armién, A.; Ruedas, L.A.; Avila, M.; Zaldívar, Y.; Pascale, J.M.; Gracia, F.; Yates, T.L. Serosurvey of wild rodents for hantaviruses in Panama, 2000-2002. J. Wildl. Dis. 2004, 40, 103-109. [CrossRef] [PubMed]

54. Berl, J.L.; Kuenzi, A.J.; Flaherty, E.A.; Swihart, R.K. Interspecific comparison of hantavirus prevalence in Peromyscus populations from a fragmented agro-ecosystem in Indiana, USA. J. Wildl. Dis. 2017, 54, 147-150. [CrossRef] [PubMed]

55. Vigueras-Galván, A.L.; López-Pérez, A.M.; García-Peña, G.E.; Rico-Chávez, O.; Sarmiento-Silva, R.E.; Suzán, G. Current situation and perspectives on hantaviruses in Mexico. Viruses 2019, 11, 642. [CrossRef] [PubMed]

56. Hjelle, B.; Glass, G.E. Outbreak of hantavirus infection in the four corners region of the United States in the wake of the 1997-1998 El Niño-southern oscillation. J. Infect. Dis. 2000, 181, 1569-1573. [CrossRef] [PubMed]

57. Glass, G.E.; Shields, T.; Cai, B.; Yates, T.L.; Parmenter, R. Persistently highest risk areas for hantavirus pulmonary syndrome: Potential sites for refugia. Ecol. Appl. 2007, 17, 129-139. [CrossRef] 
58. Madhav, N.K.; Wagoner, K.D.; Douglass, R.J.; Mills, J.N. Delayed density-dependent prevalence of Sin Nombre virus antibody in Montana deer mice (Peromyscus maniculatus) and implications for human disease risk. Vector Borne Zoonotic Dis. 2007, 7, 353-364. [CrossRef] [PubMed]

59. Adler, F.R.; Pearce-Duvet, J.M.C.; Dearing, M.D. How host population dynamics translate into time-lagged prevalence: An investigation of Sin Nombre virus in deer mice. Bull. Math. Biol. 2008, 70, 236-252. [CrossRef] [PubMed]

60. Lehmer, E.M.; Clay, C.A.; Pearce-Duvet, J.; St Jeor, S.; Dearing, M.D. Differential regulation of pathogens: The role of habitat disturbance in predicting prevalence of Sin Nombre virus. Oecologia 2008, 155, 429-439. [CrossRef]

61. Suzán, G.; Marce, E.; Giermakowski, J.T.; Mills, J.N.; Ceballos, G.; Ostfeld, R.S.; Armién, B.; Pascale, J.M.; Yates, T.L. Experimental evidence for reduced rodent diversity causing increased hantavirus prevalence. PLoS ONE 2009, 4, e5461. [CrossRef]

62. Suzán, G.; Armién, A.; Mills, J.N.; Marce, E.; Ceballos, G.; Ávila, M.; Salazar-Bravo, J.; Ruedas, L.; Armién, B.; Yates, T.L. Epidemiological considerations of rodent community composition in fragmented landscapes in Panama. J. Mammal. 2008, 89, 684-690. [CrossRef]

63. Murúa, R.; Navarrete, M.; Cádiz, R.; Figueroa, R.; Padula, P.; Zaror, L.; Mansilla, R.; González, L.; Muñoz-Pedreros, A. Síndrome pulmonar por hantavirus: Situación de los roedores reservorios y la población humana en la Décima Región, Chile. Rev. Med. Chil. 2003, 131, 169-176. [CrossRef] [PubMed]

64. Geoghegan, J.L.; Holmes, E.C. The phylogenomics of evolving virus virulence. Nat. Rev. Genet. 2018, 19, 756-769. [CrossRef] [PubMed]

65. Baró, M.; Vergara, J.; Navarrete, M. Hantavirus in Chile: Review and cases analysis since 1975. Rev. Med. Chil. 1999, 127, 1513-1523. [CrossRef] [PubMed]

66. Pavletic, C. Hantavirus: Geographical distribution among the wild rodents in Chile. Rev. Chil. Infectol. 2000, 17, 186-196.

67. Polop, F.J.; Provensal, M.C.; Pini, N.; Levis, S.C.; Priotto, J.W.; Enria, D.; Calderón, G.E.; Costa, F.; Polop, J.J. Temporal and spatial host abundance and prevalence of Andes hantavirus in Southern Argentina. Ecohealth 2010, 7, 176-184. [CrossRef]

68. Yanagihara, R.; Gu, S.H.; Arai, S.; Kang, H.J.; Song, J.W. Hantaviruses: Rediscovery and new beginnings. Virus Res. 2014, 187, 6-14. [CrossRef] [PubMed]

69. Calisher, C.H.; Wagoner, K.D.; Amman, B.R.; Root, J.J.; Douglass, R.J.; Kuenzi, A.J.; Abbott, K.D.; Parmenter, C.; Yates, T.L.; Ksiazek, T.G.; et al. Demographic factors associated with prevalence of antibody to Sin Nombre Virus in deer mice in the Western United States. J. Wildl. Dis. 2007, 43, 1-11. [CrossRef]

70. Glass, G.E.; Livingstone, W.; Mills, J.N.; Hlady, W.G.; Fine, J.B.; Biggler, W.; Coke, T.; Frazier, D.; Atherley, S.; Rollin, P.E.; et al. Black creek canal virus infection in Sigmodon hispidus in Southern Florida. Am. J. Trop. Med. Hyg. 1998, 59, 699-703. [CrossRef]

71. Yahnke, C.J.; Meserve, P.L.; Ksiazek, T.G.; Mills, J.N. Patterns of infection with Laguna Negra virus in wild populations of Calomys laucha in the central Paraguayan chaco. Am. J. Trop. Med. Hyg. 2001, 65, 768-776. [CrossRef]

72. Cantoni, G.; Padula, P.; Calderón, G.; Mills, J.; Herrero, E.; Sandoval, P.; Martinez, V.; Pini, N.; Larrieu, E. Seasonal variation in prevalence of antibody to hantaviruses in rodents from southern Argentina. Trop. Med. Int. Heal. 2001, 6, 811-816. [CrossRef]

73. Piudo, L.; Monteverde, M.J.; Walker, R.S.; Douglass, R.J. Oligoryzomys longicaudatus characteristics' associated with the presence of Andes virus (Hantavirus). Rev. Chil. Infectología 2012, 29, 200-206. [CrossRef] [PubMed]

74. Gieseke, J. Modern Infectious Diseases Epidemiology.; Edward Arnold: London, UK, 1994.

75. Juan, E.E.; Provensal, M.C.; Steinmann, A.R. Space use and social mating system of the hantavirus host, Oligoryzomys longicaudatus. Ecohealth 2018, 15, 96-108. [CrossRef] [PubMed]

76. Polop, F.; Levis, S.; Pini, N.; Enría, D.; Polop, J.; Provensal, M.C. Factors associated with hantavirus infection in a wild host rodent from Cholila, Chubut Province, Argentina. Mamm. Biol. 2018, 88, 107-113. [CrossRef]

77. Mills, J.N.; Amman, B.R.; Glass, G.E. Ecology of hantaviruses and their hosts in north america. Vector Borne Zoonotic Dis. 2010, 10, 563-574. [CrossRef] [PubMed]

78. Glass, G.E.; Childs, J.E.; Korch, G.W.; Leduc, J.W. Association of intraspecific wounding with hantaviral infection in wild rats (Rattus norvegicus). Epidemiol. Infect. 1988, 101, 459-472. [CrossRef] [PubMed] 
79. Mills, J.N.; Yates, T.L.; Ksiazek, T.G.; Peters, C.J.; Childs, J.E. Long-term studies of hantavirus reservoir populations in the southwestern United States: Rationale, potential, and methods. Emerg. Infect. Dis. 1999, 5 , 95-101. [CrossRef] [PubMed]

80. Douglass, R.J.; Calisher, C.H.; Wagoner, K.D.; Mills, J.N. Sin Nombre virus infection of deer mice in Montana: Characteristics of newly infected mice, incidence, and temporal pattern of infection. J. Wildl. Dis. 2007, 43, 12-22. [CrossRef]

81. Bagamian, K.H.; Towner, J.S.; Kuenzi, A.J.; Douglass, R.J.; Rollin, P.E.; Waller, L.A.; Mills, J.N. Transmission ecology of Sin Nombre hantavirus in naturally infected North American deermouse populations in outdoor enclosures. PLOS ONE 2012, 7, e47731. [CrossRef]

82. Calisher, C.H.; Sweeney, W.; Mills, J.N.; Beaty, B.J. Natural history of Sin Nombre virus in Western Colorado. Emerg. Infect. Dis. 1999, 5, 126-134. [CrossRef]

83. Hinson, E.R.; Shone, S.M.; Zink, M.C.; Glass, G.E.; Klein, S.L. Wounding: The primary mode of Seoul virus transmission among male Norway rats. Am. J. Trop. Med. Hyg. 2004, 70, 310-317. [CrossRef]

84. Klein, S.L.; Zink, M.C.; Glass, G.E. Seoul virus infection increases aggressive behaviour in male Norway rats. Anim. Behav. 2004, 67, 421-429. [CrossRef]

85. Gonzalez, L.A.; Gaete, H.; Jofre, C.; Gonzalez, L.A.; Gaete, H.; Jofre, C. Variación estacional de los patrones conductuales en Oryzomys longicaudatus y Akodon olivaceus en encuentros intraespecíficos e interespecíficos. Bol. Soc. Biol. Concepc. 1990, 61, 63-70.

86. Larrieu, E.; Cantoni, G.; Herrero, E.; Perez, A.; Talmon, G.; Vazquez, G.; Arellano, O.; Padula, P. Hantavirus antibodies in rodents and human cases with pulmonary syndrome, Rio Negro, Argentina. Medicina 2008, 68, 373-379. [PubMed]

87. Astorga, F.; Escobar, L.E.; Poo-Muñoz, D.; Escobar-Dodero, J.; Rojas-Hucks, S.; Alvarado-Rybak, M.; Duclos, M.; Romero-Alvarez, D.; Molina-Burgos, B.E.; Peñafiel-Ricaurte, A.; et al. Distributional ecology of Andes hantavirus: A macroecological approach. Int. J. Health Geogr. 2018, 17, 1-12. [CrossRef] [PubMed]

88. Linard, C.; Tersago, K.; Leirs, H.; Lambin, E.F. Environmental conditions and Puumala virus transmission in Belgium. Int. J. Heal. Geogr. 2007, 6, 55. [CrossRef] [PubMed]

89. Torres-Pérez, F.; Palma, R.E.; Hjelle, B.; Holmes, E.C.; Cook, J.A. Spatial but not temporal co-divergence of a virus and its mammalian host. Mol. Ecol. 2011, 20, 4109-4122. [CrossRef] [PubMed]

90. Veblen, T.T. Temperate forests of the Southern Andean Region. In The Physical Geography of South America; Veblen, T.T., Orme, A.R., Young, K.R., Eds.; Oxford University Press: Oxford, UK, 2007; pp. 217-231.

91. Armesto, J.J.; Arollo, M.T.K.; Hinojosa, F. The Mediterranean environment of central Chile. In The Physical Geography of South America; Veblen, T.T., Young, K.R., Orme, A.R., Eds.; Oxford University Press: New York, NY, USA, 2007; pp. 184-199.

92. Palma, R.E.; Boric-Bargetto, D.; Torres-Pérez, F.; Hernández, C.E.; Yates, T.L. Glaciation effects on the phylogeographic structure of Oligoryzomys longicaudatus (Rodentia: Sigmodontinae) in the Southern Andes. PLoS ONE 2012, 7, e32206. [CrossRef]

93. Lazo-Cancino, D.; Musleh, S.S.; Hernandez, C.E.; Palma, E.; Rodriguez-Serrano, E. Does silvoagropecuary landscape fragmentation affect the genetic diversity of the sigmodontine rodent Oligoryzomys longicaudatus? PeerJ 2017, 5, e3842. [CrossRef]

94. Palma, R.E.; Cancino, R.A.; Rodríguez-Serrano, E. Molecular systematics of Abrothrix longipilis (Rodentia: Cricetidae: Sigmodontinae) in Chile. J. Mammal. 2010, 91, 1102-1111. [CrossRef]

95. Rodríguez-Serrano, E.; Cancino, R.A.; Palma, R.E. Molecular phylogeography of Abrothrix olivaceus (Rodentia: Sigmodontinae) in Chile. J. Mammal. 2006, 87, 971-980. [CrossRef]

96. Belmar-Lucero, S.; Godoy, P.; Ferrés, M.; Vial, P.; Palma, R.E. Range expansion of Oligoryzomys longicaudatus (Rodentia, Sigmodontinae) in Patagonian Chile, and first record of hantavirus in the region. Rev. Chil. Hist. Nat. 2009, 82, 265-275. [CrossRef]

97. Carver, S.; Mills, J.N.; Parmenter, C.A.; Parmenter, R.R.; Richardson, K.S.; Harris, R.L.; Douglass, R.J.; Kuenzi, A.J.; Luis, A.D. Toward a mechanistic understanding of environmentally forced zoonotic disease emergence: Sin nombre hantavirus. Bioscience 2015, 65, 651-666. [CrossRef] [PubMed]

98. Guterres, A.; de Lemos, E.R.S. Hantaviruses and a neglected environmental determinant. One Heal. 2018, 5, 27-33. [CrossRef] [PubMed]

99. Langlois, J.P.; Fahrig, L.; Merriam, G.; Artsob, H. Landscape structure influences continental distribution of hantavirus in deer mice. Landsc. Ecol. 2001, 16, 255-266. [CrossRef] 
100. Rynkiewicz, E.C.; Pedersen, A.B.; Fenton, A. An ecosystem approach to understanding and managing within-host parasite community dynamics. Trends Parasitol. 2015, 31, 212-221. [CrossRef] [PubMed]

101. Barrera, K.; Murua, R. Nuevo desafío en Salud Pública: Presencia de reservorios de Hanta, Oligoryzomys longicaudatus y Rattus spp., en aéreas de borde en praderas del sur de Chile. Sustain. Agri. Food Environ. Res. 2015, 3, 33-46.

102. Monteverde, M.J.; Hodara, K. Movimientos de roedores intra-e inter-ambiente y riesgo de exposición al hantavirus Andes en Patagonia Norte, Argentina. Ecol. Austral 2017, 27, 279-289. [CrossRef]

103. Belay, E.D.; Kile, J.C.; Hall, A.J.; Barton-behravesh, C.; Parsons, M.B.; Salyer, S.; Walke, H. Zoonotic disease programs for enhancing global health security. Emerg. Infect. Dis. 2017, 23, 65-70. [CrossRef] [PubMed]

104. Plowright, R.K.; Parrish, C.R.; Mccallum, H.; Hudson, P.J.; Ko, A.I.; Graham, A.L.; Lloyd-smith, J.O. Pathways to zoonotic spillover. Nat. Publ. Gr. 2017, 15, 502-510. [CrossRef] [PubMed]

(C) 2019 by the authors. Licensee MDPI, Basel, Switzerland. This article is an open access article distributed under the terms and conditions of the Creative Commons Attribution (CC BY) license (http://creativecommons.org/licenses/by/4.0/). 